\title{
Geographical Information System (GIS) and Analytical Hierarchy Process (AHP) based groundwater Potential Zones delineation in Chennai River Basin (CRB), India
}

Sajil Kumar PJ ( $\square$ pjsajil@gmail.com )

Freie Universität Berlin https://orcid.org/0000-0002-9050-1807

\section{Elnago L}

Anna University Chennai

Michael Schneider

Freie Universitat Berlin

\section{Research Article}

Keywords: Groundwater Potential, AHP, Thematic Layers, GIS, Chennai River Basin

Posted Date: August 6th, 2021

DOI: https://doi.org/10.21203/rs.3.rs-730560/v1

License: (c) This work is licensed under a Creative Commons Attribution 4.0 International License. Read Full License 


\section{Abstract}

Groundwater depletion is one of the most important concerns for users and policy makers. Information on the locations where groundwater potential is high, or low is the key factor that helps them to do proper planning. Application of new technologies and methods are essential in this situation. This study has used the possibilities of Geographical Information System (GIS), Remote Sensing and, of course, field data to delineate the groundwater potential zones in the Chennai River Basin (CRB). To provide accurate results, 11 controlling factors- geology, water level, drainage, soil, lineament, rainfall, land use, slope, aspect, geomorphology, and depth to bed rock-- were brought into a digital GIS environment and appropriate weightage given to each layer depending on their effect on potential. The weightage is given based on Multi-Criteria Decision Making (MCDM), namely Analytical Hierarchal Process (AHP). Groundwater potential zones in the CRB were mapped as very poor, poor, moderate, good, very good using weighted overlay analysis. The results were compared with actual specific capacity from the borehole data. The accuracy of prediction was found to be $78.43 \%$, indicating that in most of the locations, the predicted potential map agrees with the bore hole data. Thus, AHP aided GIS-RS mapping is a useful tool in groundwater prospecting in this region of the world.

\section{Introduction}

According to availability and ease of access, surface water may be the most depended upon source of water for drinking and domestic purposes. However, with increased industrialization and urbanization, surface water faces serious threats in terms of quality. On a global scale, groundwater serves $50 \%$ of drinking and $43 \%$ of irrigation needs (FAO 2010). India is one the largest users of groundwater resources and the usage is increasing drastically (Postal 1999). As an agriculturally lead economy, $80 \%$ of the groundwater in India is used for irrigation (Dhavan 2017), and remaining is used for drinking, domestic and industrial purposes. Uncontrolled pumping has lowered the groundwater level severely and reported as overexploited in many parts of India (Dhavan 2017).

Chennai is the fourth largest metropolitan area in India and the biggest urban area in the Chennai River Basin (CRB). One of the earliest acts on the regulation of groundwater use and policy in India was The Chennai Metropolitan Area Groundwater (Regulation) Act in 1987, which banned the extraction of groundwater at 229 locations (Jenifer and Arul 2102). Further amendments to this restriction were made in 1995 and 2008. Rapid increase in population, industrialization, urbanization and irrigation have resulted in a huge demand of water from the Chennai Basin. Geographically, the eastern boundary of the basin is long coastline of the Bay of Bengal. Sea water intrusion into the freshwater zones and groundwater quality deterioration has been reported (Elango and Manickam 1986; Sajil Kumar et al., 2013; Nair et al., 2015). In this region, groundwater depletion and pollution affect the population and the economy, calling for sustainable water resources management. Previous studies suggests that most of the studies in this region focusing on groundwater quality, saline intrusions, hydrochemical investigations, managed aquifer recharge etc., (Elango et al., 1992; Senthik Kumar et al., 2001; Sathish et al., 2011; Parimala and Elango 2013; Raicy and Elango 2017). All these studies were performed at a watershed or sub-basin level. A more holistic approach is needed because the groundwater supply to the city also includes the well fields located north of Chennai. Thus, a study must be performed on the complete basin, with a special emphasis on the urban area.

Estimating groundwater reserve and the demarcation of prospective zones is the preliminary step of any water resources management project. Accurate calculation of inputs (recharge) and outputs (discharge) is essential at this stage. Systematic planning of groundwater exploitation using modern techniques is necessary for the proper utilization and management of this precious but shrinking natural resource (Chowdhury 2007). The use of conventional techniaues like aeoloaical. aeophysical, geostatistical and numerical modeling is expensive, laborious Loading [MathJax]/jax/output/CommonHTML/jax.js

Page 2/33 
and time consuming (Elbeih 2014). The rapid growth of space technology has played a vital role in groundwater studies. Remote Sensing (Rs) and Geographic Information System (GIS) are promising tools for efficient planning and management of groundwater resources (Machiwal 2011). NRSA in India is one of the pioneers in using the integrated study of RS and GIS for delineating groundwater recharge potential in an area (NRSA 1987). Geospatial technologies provide cost-effective solutions for the aquifer management and integration of multi thematic data sets to a uniform scale.

The use of RS and GIS extensively used in India for the mapping and montoring of the groundwater potential zones and locating the suitable locations for the artificial groundwater recharge (Prasad et. al., 2008; Singh et al., 2013; Nagaraju et al., 2011 ; Magesh et al., 2012; Nag and Gosh 2013; Murthy et al., 2013 and many more). There are many studies found in many parts of India (Kurmapalli watershed Andharapradesh), (Bist Doab Basin, punjab), (Chamarajnagar District, Karnataka), (Bankura District, West Bengal), (Vamshadhara basin, Andhra Pradesh), (Theni district Tamil Nadu) and many more., on groundwater potential zone delineation using GIS techniques. The present study is concentrated mainly on the estimation of groundwater reserve and mapping groundwater potential zones in Chennai River Basin (CRB). We aim to create a basic platform for the sustainable groundwater management in future.

\section{Study Area Settings}

Chennai basin is located in the North-East region of Tamil Nadu State with latitudes $12^{\circ} 40^{\prime} \mathrm{N}$ and $13^{\circ} 40^{\prime} \mathrm{N}$ and longitudes $79^{\circ} 10^{\prime} \mathrm{E}$ and $80^{\circ} 25^{\prime} \mathrm{E}$. The major portion of the basin is in Tamil Nadu and the remaining in the Andhra Pradesh state. The climate of the study area is semi-arid tropical, with temperature ranging from $13.9^{\circ} \mathrm{C}$ to $45^{\circ} \mathrm{C}(\mathrm{CGWB}$ 2008). The highest temperature is recorded in Chennai in Summer season and the lowest in Tiruthani in Winter season. Variation in the availability of sunshine is mostly by the season. The location map of the study area is shown in Fig. 1. On an average the annual rainfall is $1156 \mathrm{~mm} /$ year. Relative humidity in the basin is varies from 53 to $84 \%$ and the wind velocity varies from 5.69 to $14.15 \mathrm{~km} / \mathrm{hr}$. Geomorphology of an area represents the origin, structure, development of landforms and alteration by human beings. Geomorphology can also hint to the underlying futures and also the processes that controls the evolution of the land forms. A wide range of geomorphological features are available in the study area. The major formations are beaches, Beach Ridges, Beach terraces, Buried Pediments, Wash Plains, Salt Pans, Swamps, Swale, Deltaic Plains, Deep Pediment, Pediment and Shallow Pediment, Buried Course \& Channels, Tertiary Uplands, Flood Plains, Piedmont, and Inter Fluveo. Geologically Chennai basin is overlaid by the Precambrian gneisses and Charnockites and above which the marine and estuarine fluvial alluvium. The hard rocks include granite, gneissic complex, schist's and chamockites associated with basic and ultra-basic intrusive. The chamockites form the major rock types and constitute the residual hills around Pallavaram, Tambaram and Vandalur. Among the sedimentary formation's conglomerates, shale, and sandstone, and are covered by a thick cover of laterite. Tertiary sandstone is seen in small patches in the area around Perambur, and around northwest of Chennai city and up to Satyavedu, and is capped by lateritic soil. In the Chennai basin four different types of Soils were observed (i) Entisols, (ii) Inceptisols, (iii) Vertisols and (iv) Alfisols. The main aquifer system of the Chennai basin is formed by the river alluvium as well as Tertiary formations of the AK basin. The groundwater is mainly recharged by the rainfall recharge and river network. In the northern part, Minjur aquifer is already overexploited and facing threat from the seawater intrusion. South Chennai coastal aquifer is also not an exception. The present situation at the study area calling for immediate action to identify the groundwater potential zone and artificial recharge to protect the groundwater reserve.

Figure 1 Location map of the study area

\section{Data And Methods}

Loading [MathJax]/jax/output/CommonHTML/jax.js 
Factors influencing groundwater recharge are determined based on literature survey, field analysis and expert opinion. Based on this preliminary investigation geomorphology, geology, lineament, annual rainfall, pre-monsoon water level, depth to bed rock, soil, land use, aspect and slope were chosen as main factors. All these maps where digitized and integrated into a GIS platform using ArcGIS 10.2. The map layers used, and their hydrogeological significance are summarized in Table 1. Conventional data sets, such as topographical maps and field data, were used along with advanced data sets, such as satellite data. Corresponding topographic maps were collected from Survey of India (SOI), with a scale of 1:150,000. These maps were digitized in the GIS environment using ArcGIS 10.1. A geological and geomorphological map for the study were prepared from the SOI maps and soil map from the National Bureau of Soil Science and Land Use Planning (NBSS and LUP). SRTM -DEM were used to derive the slope maps. A flow chart of the adopted methodology is shown in Fig. 2

Table 1

Phenomenon and need for the thematic layers

\begin{tabular}{|c|c|c|c|}
\hline No. & Map Layer & Phenomenon & Need \\
\hline 1 & Geomorphology (GM) & $\begin{array}{l}\text { Physical processes on the earth's surface } \\
\text { that produce different landforms }\end{array}$ & $\begin{array}{l}\text { A geomorphic unit is a composite } \\
\text { unit that has specific characteristics }\end{array}$ \\
\hline 2 & Geology (GEOL) & Different lithological formations & $\begin{array}{l}\text { The aquifer characteristics of } \\
\text { different geology is varied } \\
\text { considerably }\end{array}$ \\
\hline 3 & $\begin{array}{l}\text { Lineament (including } \\
\text { Fault \& Shear zone) } \\
\text { (Ln) }\end{array}$ & $\begin{array}{l}\text { Planes/Zones of structural weakness in } \\
\text { the rocks }\end{array}$ & $\begin{array}{l}\text { Easy movement of water along } \\
\text { weak planes }\end{array}$ \\
\hline 4 & Rainfall (Rf) & Rainfall & Major source of water \\
\hline 5 & $\begin{array}{l}\text { Groundwater level } \\
\text { (GWL) }\end{array}$ & $\begin{array}{l}\text { Depth at which water occurs in the } \\
\text { unconfined zone (top zone) below ground } \\
\text { level }\end{array}$ & Accessible of water \\
\hline 6 & Soil (SI) & Soil & $\begin{array}{l}\text { Result of physical surface } \\
\text { processes and the lithology }\end{array}$ \\
\hline 7 & Landuse (LU) & $\begin{array}{l}\text { Purpose for which land has been put to } \\
\text { use }\end{array}$ & Indicates the state of current use \\
\hline 8 & $\begin{array}{l}\text { Depth to Bed rock } \\
\text { (DBR) }\end{array}$ & $\begin{array}{l}\text { Massive rock below the soil and the } \\
\text { weathered zone }\end{array}$ & $\begin{array}{l}\text { Indication of the thickness of the } \\
\text { unconfined aquifer }\end{array}$ \\
\hline 9 & Slope (Sp) & Slope & $\begin{array}{l}\text { Controls the movement of water } \\
\text { (surface and ground) }\end{array}$ \\
\hline 10 & Drainage $(D)$ & Drainage & \\
\hline 11 & Aspect (A) & & \\
\hline
\end{tabular}

Figure 2 Flow chart showing the methodology adopted in the study

\section{Table 1: Phenomenon and need for the thematic layers}

Data for the analysis was available in vector (from existing maps) and raster (interpolated from point data or classified from satellite images) formats. For rainfall, depth to bed rock, water level, and elevation, layers were created from the point data sources by the Inverse Distance Weighted (IDW) interpolation method. In the IDW method, the unknown data points are calculated from the four surrounding known data points. We opted for IDW over distance threshold methods, 
because the point data was sparse and distributed. The slope map was derived from the elevation contours from the Survey of India topographical maps of the study area.

Analytical Hierarchical Process (AHP), which was originally proposed by Saaty (1990), were used for assigning the weights for each thematic layer used in this study. AHP is one of the most commonly used multi criteria decision making technique in the field of environmental and groundwater studies (Das and Mukhopadhyay 2018; Rahmati et al. 2015).

In this method a pairwise comparison matrix is generated by comparing the assigned scores for each layer. The scores are generally assigned between 1 (equal importance) and 9 (extreme importance) (Table 2; Saaty 1990). In the AHP model, a pairwise comparison matrix for the 11 layers was created. And the normalized weights of the individual layers were created using the eigen vector method.

Table 2

Saaty's scale for assignment of weights and the pairwise comparison process (Saty 1980)

\begin{tabular}{|lllllllll|}
\hline \multicolumn{2}{|l|}{ Less Important } & \multicolumn{7}{c|}{$\begin{array}{l}\text { Equally } \\
\text { important }\end{array}$} \\
\hline Extremely & $\begin{array}{l}\text { Very } \\
\text { Strongly }\end{array}$ & Strongly & Moderetely & Equally & Moderately & Strongely & $\begin{array}{l}\text { Very } \\
\text { Strongly }\end{array}$ & Extremely \\
$1 / 9$ & $1 / 7$ & $1 / 5$ & $1 / 3$ & 1 & 3 & 5 & 7 & 9 \\
\hline
\end{tabular}

Table 2: Saaty's scale for assignment of weights and the pairwise comparison process (Saty 1980)

The weight of each thematic layer is derived from the maximum eigen value in the normalized eigen value in the pairwise comparison matrix. The reliability of the judgment is dependent on the Consistency Ratio (CR) and its value must be less than or equal to 0.1 . In case it exceeds this limit, it is suggested to revise the process. CR is calculated as follows,

$C R=C I / R I$

Here RI is the Random Consistency Index (see Table 3) and Cl is the Consistency Index, which is calculated as follows,

Table 3

Random indices for matrices of various sizes

\begin{tabular}{|llllllllllll|}
\hline Matrix Size & $\mathbf{1}$ & $\mathbf{2}$ & $\mathbf{3}$ & $\mathbf{4}$ & $\mathbf{5}$ & $\mathbf{6}$ & $\mathbf{7}$ & $\mathbf{8}$ & $\mathbf{9}$ & $\mathbf{1 0}$ & $\mathbf{1 1}$ \\
\hline $\mathrm{RI}$ & 0 & 0 & 0.58 & 0.90 & 1.12 & 1.24 & 1.32 & 1.41 & 1.45 & 1.49 & 1.51 \\
\hline
\end{tabular}

$C I=\frac{\lambda_{\max }-\mathrm{n}}{n-1}$

In this equation, $\lambda$ is the Principal eigen value of the matrix and $\mathrm{n}$ is the number factors used in the estimation (Saty 1980).

\section{Table 3: Random indices for matrices of various sizes}

Groundwater potential zones were derived from 11 thematic layers integrated into the GIS environment to calculate the groundwater potential index (GWPI). This is done by Weighted Linear Combination (WLC), as suggested by Malczewski 


$$
G W P I=\sum_{W=1}^{m} \sum_{1}^{n}(W j \times X I)
$$

Here GWPI is the Groundwater Potential Index, $X_{i}$ is the normalized weight of the $i^{\text {th }}$ feature of the thematic layer, $w_{j}$ is the normalized weight of the $\mathrm{j}^{\text {th }}$ thematic layer, $\mathrm{m}$ represents total number of themes, and $\mathrm{n}$ is the total number of classes in a theme.

\section{Results And Discussion}

\subsection{Thematic Layers and Features in the CRB}

Mapping and analysis of slope

Slope is an important geomorphological feature that affects the groundwater potential of a region and an important parameter in identifying groundwater recharge prospects (Fasche et al., 2014). Groundwater potential is greater in gentle slopes as more infiltration occurs due to the increased residence time. On the other hand, the increased runoff rate for steep slopes makes them less suitable for groundwater recharge. In this study, slope varies from 0 to $80.44 \%$, the majority of the area having a slope between 0 to $4.73 \%$. The highest slopes were found mostly in the western region of the study area. Based on this, the slope range between $0-4.73 \%$ was given a weightage of 7 (very good) with 4 (moderate), 3(moderate) and 2 (poor) given to subsequent classes (see Fig. 3). Generally, steep slopes are given lower weights and gentle slope with higher weights (Agarwal and Garg 2016).

Figure 3 Slope Map

Mapping and analysis of aspect

Aspect is an important terrain characteristic that affects the groundwater recharge characteristics of a basin. It is the direction of slope usually measured clockwise from 0 to $360^{\circ}$. Zero means the aspect facing north, 90,180 is southfacing, and 270 is west-facing. In arid and semi-arid regions, microclimatic changes are dependent on slope exposure direction and drainage basin development. Thus, aspect has a direct influence on the microclimates (Hadley 1961; AlSaady et al., 2016). An aspect map of the study area is shown in Fig. 4. The aspect of CRB is trending towards all the directions, however higher weightage is given to the flat terrains and the lowest to those areas trending north. terrains and the lowest to the north trending areas.

Figure 4 Aspect Map

Mapping and analysis of groundwater level

In Unsaturated conditions, the upper level of saturated underground surface in which water pressure equals the atmospheric pressure is known as groundwater table (Freeze and Cherry 1979). Depth to the water table is a measure of groundwater recharge or discharge. When the water table is deep, the flow is towards the water table via percolation and infiltration. On the other hand, when the water table meets the land surface, the flow is away from the water table. (Poehls and Smith 2009). So, for potential recharge zones, the higher depth to the water table is an essential factor. The groundwater level in the study area varies from 0 to $21 \mathrm{~m}$ below ground level. Most of the region in the study area falls between 6 and $11 \mathrm{~m}$ below ground level(mbgl) (Fig. 5). As the depth to the water table increases, the possibility of recharge increases because of the increased storage in aquifers. Greater weight is given to those regions where the depth to the water table is high and vice versa.

Loading [MathJax]/jax/output/CommonHTML/jax.js 
Figure 5 Groundwater Level Map

Mapping and analysis of rainfall

Rainfall data for the past 44 years has been collected by the India Meteorological Department (IMD). A spatial variation map of the rainfall was created with the IDW interpolation method. The minimum and maximum rainfall received in the Chennai Basin were 770 and $1570 \mathrm{~mm}$, respectively. The coastal part of the basin is receiving a high amount of rainfall, compared to the western part. A spatial map of rainfall in the Chennai Basin is given in Fig. 6 .

Figure 6 Rainfall map

Mapping and analysis of Lithology

The geology of an area is one of the key factors in groundwater potential zone delimitation. Various geological formations have different water bearing capacities and subsurface flow characteristics. A considerable variation in the water bearing capacities may be found between sedimentary to Igneous and metamorphic rocks of recent to Precambrian periods (see Fig. 7). The other principal factor is the weathering of the rocks, which increase the groundwater potential of the area. The Chennai basin exhibited a wide range (sedimentary-Metamorphic-lgneous) of geological formations. Starting from the eastern coastal region, a long stretch of coastal Alluvium is observed throughout the study area and charockites in the southern edge. From the middle to north alluvial formation begins and extend to greater areas towards the west. Laterites are found in the northern part of the basin and also spread in between the alluvial formations. In the southern part, just near to the charnockite, there are thick shale sandstone formations. The western end of the area is marked by biotite hornblende gneiss, with lengthy patch of hornblendeepidote. Geology of the area suggests that the possible high groundwater bearing formations are alluvium and sandstones Considering the geology of the area, alluviums, sandstone are promising locations for groundwater development. However, the degree of weathering, lineament and fractures determine the same for the hard rock formations.

Figure 7 Geological of the study area

Mapping and analysis of Drainage

The drainage network map of the Chennai Basin is shown in Fig. 8. The Chennai Basin has many rivers, tanks and reservoirs. Since the basin has mostly permeable formations as well as built-up areas, the drainage density of the basin is very low. Thus, the main features are classified as rivers, tanks/reservoirs and others. Suitable ranking is given to each feature depending on their groundwater potentiality.

Figure 8 Drainage Map

Mapping and analysis of soils

Soils in the study area can be classified into Clay, clay loam, loamy sand, Sand, Sandy Clay, Sandy-clay- loam, Sandy loam, as shown in Fig. 9. Along the beeches sandy and sandy clay loam types are present, and these formations are permeable and can be a aquifer. These formations are extensively found along the East Coast Road (ECR), and holds good for agricultural activities.

Clayey soils are found in northern region, namely Gummidipoondi, Ponneri, Minjur, Madhavaram and Manali, and in the western portion of the East Coast Road around Thiruporur. These soils have much lower infiltration rates. Weights

Loading [MathJax]/jax/output/CommonHTML/jax.js 
assigned for the soil layer are mainly based on the infiltration rate. As a result, clayey soils have been given the lowest weights, while sandy soil receives the highest.

Figure 9 Soil map

Mapping and analysis of land use

The rapid increase in population resulted in extensive changes in the land use pattern of the CRB. Groundwater recharge is largely controlled by the landuse. Hence, a proper understanding of land use is necessary for the sustainable groundwater development. Overexploitation of water resources for various purposes has a severe impact on the water system. Increased water exploitation has led to a reduction in water recharge and groundwater storage of the area. The various land use patterns of the study area are presented in Fig. 10. Cropland, mangroves, shrubs, and Casuarina cover a majority of the study area.

Figure.10 Land-use map of Chennai Basin

Mapping and analysis of Lineaments

Lineaments are rectilinear alignments observed on the surface of the earth, which are representations of geological or geomorphological events. They can be observed as straight lines in digital data, which represent a continuous series of pixels having similar terrain values. Large scale lineaments can be identified from remotely sensed images.

Lineaments are the primary indicators of secondary porosity and also for potential sources of water supply. The presence of lineaments is observed in all directions in the study area. The lineament density seems to be very high in Takkolam, Cooum, Sriperumbudur, Thiruvallur, Thiruthani, etc (Fig. 11).

Figure 11: Lineaments Map

Mapping and analysis of geomorphology

The Chennai Basin has exceptionally versatile geomorphological features with beaches, Beach Ridges, Beach terraces, Buried Pediments, Wash Plains, Salt Pans, Swamps, Swale, Deltaic Plains, Deep Pediment, Pediment and Shallow Pediment, Buried Course \& Channels, Tertiary Uplands, Flood Plains, Piedmont, Inter Fluveo. The presence of rivers, coastal regions, hills and plain land make this area an example of a complex geomorphological set up. It has a long coastal belt on the eastern boundary where the city of Chennai is located, with one of the thickest populated regions in southern India. The NE boundary of the study area has a long portion with Duricrust, a hard mineral layer on top of the sedimentary formations. Tertiary laterites are found as patches all along the basin. In the western part structural hills are visible. Lower Gondwana formations are seen in the southern and central parts. Upper Gondwana formations are Pediments seen in the Tambaam region pat of the city. At the northern part, along the state boundary of Andhra Pradesh, tertiary uplands form a larger area and the same is present in available north of the city. A detailed geomorphological map of the study area is shown in Fig. 12.

Figure12 Geomorphology map of the study area.

Mapping and analysis of Depth to bed Rock

Depth to bed rock is a representation of the thickness of unconsolidated or weathered formations in the area. The depth to bed rock of CRB varied from 11 to $829 \mathrm{~m}$ (Fig. 13). Southern coastal regions and western part of CRB has weathered thickness upto $45 \mathrm{~m}$. The deepest depth to bed rock is found in the extreme north region. Based on these

Loading [MathJax]/jax/output/CommonHTML/jax.js 
values, three major categories such as poor, moderate and very good, with corresponding weights 5,6 and 8 were assigned for the layer.

Figure 13: depth to bed rock

\subsection{Normalized weights for thematic maps}

The pairwise comparison matrix of the groundwater prospecting thematic layers were derived based on the AHP method. The weights were normalized and the weights for individual thematic layers are calculated by Eigen vector method (Table 4).

Table 4

Pairwise comparison matrix of 11 groundwater prospecting parameters for AHP

\begin{tabular}{|c|c|c|c|c|c|c|c|c|c|c|c|}
\hline Thematic Layer & Sp & $A$ & GWL & RF & GEO & D & SI & LU & $\operatorname{Ln}$ & GM & DBR \\
\hline Slope (Sp) & 1.00 & 0.33 & 0.33 & 0.50 & 0.50 & 0.33 & 0.33 & 0.20 & 0.25 & 0.25 & 0.25 \\
\hline Aspect (A) & 3.00 & 1.00 & 0.50 & 0.50 & 0.33 & 0.33 & 0.50 & 0.50 & 0.50 & 0.33 & 0.50 \\
\hline $\begin{array}{l}\text { Ground Water } \\
\text { level (GWL) }\end{array}$ & 3.00 & 2.00 & 1.00 & 0.25 & 0.25 & 0.25 & 0.25 & 0.33 & 0.25 & 0.25 & 0.50 \\
\hline Rainfall (RF) & 2.00 & 2.00 & 4.00 & 1.00 & 0.33 & 0.25 & 0.33 & 0.25 & 0.50 & 0.25 & 0.25 \\
\hline Geology (GEOL) & 2.00 & 3.00 & 4.00 & 3.00 & 1.00 & 0.50 & 0.33 & 0.33 & 0.50 & 0.33 & 0.25 \\
\hline Drainage(D) & 3.00 & 3.00 & 4.00 & 4.00 & 2.00 & 1.00 & 0.50 & 0.25 & 0.50 & 0.33 & 0.33 \\
\hline Soil (SL) & 3.00 & 2.00 & 4.00 & 3.00 & 3.00 & 2.00 & 1.00 & 0.50 & 0.33 & 0.50 & 0.33 \\
\hline Landuse (LU) & 5.00 & 2.00 & 3.00 & 4.00 & 3.00 & 4.00 & 2.00 & 1.00 & 0.33 & 0.50 & 0.33 \\
\hline Lineament (Ln) & 4.00 & 2.00 & 4.00 & 2.00 & 2.00 & 2.00 & 3.00 & 3.00 & 1.00 & 0.50 & 0.25 \\
\hline $\begin{array}{l}\text { Geomorphology } \\
\text { (GM) }\end{array}$ & 4.00 & 3.00 & 4.00 & 4.00 & 3.00 & 3.00 & 2.00 & 2.00 & 2.00 & 1.00 & 0.50 \\
\hline $\begin{array}{l}\text { Depth to bed } \\
\text { rock (DBR) }\end{array}$ & 4.00 & 2.00 & 2.00 & 4.00 & 4.00 & 3.00 & 3.00 & 3.00 & 4.00 & 2 & 1.00 \\
\hline SUM & 34.00 & 22.33 & 30.83 & 26.25 & 19.42 & 16.67 & 13.25 & 11.37 & 10.17 & 6.25 & 4.50 \\
\hline
\end{tabular}

Table 5 shows the normalized weights of each layer and their corresponding total weightage. The maximum weightage shows the most influential parameter, and the minimum weightage represents the least influential parameter. In the CRB, depth to bed rock or aquifer thickness play the most important role with $20.33 \%$ weightage. With $15 \%$, geomorphology was the second most important parameter. The relative importance of the other parameters are as follows, lineament (12.37\%), land use (12\%), soil (9\%), drainage (8.2\%), geology (6.6\%), rainfall (4.9\%), aspect (4.5\%), water level (4.2\%), and slope (2.6\%). 
Table 5

Calculation of Normalized weights for 11 thematic layers of CRB

\begin{tabular}{|lllllllllllll|}
\hline & Sp & A & GWL & RF & GEO & D & SI & LU & Ln & GM & DBR & Normalized weight \\
\hline Sp & 0.03 & 0.01 & 0.01 & 0.02 & 0.03 & 0.02 & 0.03 & 0.02 & 0.02 & 0.04 & 0.06 & 0.0257 \\
\hline A & 0.09 & 0.04 & 0.02 & 0.02 & 0.02 & 0.02 & 0.04 & 0.04 & 0.05 & 0.05 & 0.11 & 0.0455 \\
\hline GWL & 0.09 & 0.09 & 0.03 & 0.01 & 0.01 & 0.02 & 0.02 & 0.03 & 0.02 & 0.04 & 0.11 & 0.0429 \\
\hline Rf & 0.06 & 0.09 & 0.13 & 0.04 & 0.02 & 0.02 & 0.03 & 0.02 & 0.05 & 0.04 & 0.06 & 0.0491 \\
\hline GEOL & 0.06 & 0.13 & 0.13 & 0.11 & 0.05 & 0.03 & 0.03 & 0.03 & 0.05 & 0.05 & 0.06 & 0.0665 \\
\hline D & 0.09 & 0.13 & 0.13 & 0.15 & 0.10 & 0.06 & 0.04 & 0.02 & 0.05 & 0.05 & 0.07 & 0.0822 \\
\hline SI & 0.09 & 0.09 & 0.13 & 0.11 & 0.15 & 0.12 & 0.08 & 0.04 & 0.03 & 0.08 & 0.07 & 0.0911 \\
\hline LU & 0.15 & 0.09 & 0.10 & 0.15 & 0.15 & 0.24 & 0.15 & 0.09 & 0.03 & 0.08 & 0.07 & 0.1188 \\
\hline Ln & 0.12 & 0.09 & 0.13 & 0.08 & 0.10 & 0.12 & 0.23 & 0.26 & 0.10 & 0.08 & 0.06 & 0.1237 \\
\hline GM & 0.12 & 0.13 & 0.13 & 0.15 & 0.15 & 0.18 & 0.15 & 0.18 & 0.20 & 0.16 & 0.11 & 0.1512 \\
\hline DBR & 0.12 & 0.09 & 0.06 & 0.15 & 0.21 & 0.18 & 0.23 & 0.26 & 0.39 & 0.32 & 0.22 & 0.2033 \\
\hline & 1 & 1 & 1 & 1 & 1 & 1 & 1 & 1 & 1 & 1 & 1 & 1.000 \\
\hline
\end{tabular}

To check the consistency of the assigned weights, the consistency ratio was calculated using the formula mentioned in the methodology. For the 11 layers $(n=11)$, the consistency ratio was found as 0.98 , which is $<0.10$. This means that the weight assessment was consistent.

Table 4: Pairwise comparison matrix of 11 groundwater prospecting parameters for AHP

Table 5: Calculation of normalized weights for 11 thematic layers of CRB

Table 6: Weight assessment and normalization of different features of groundwater prospecting thematic layers 
Table 6

Weight assessment and normalization of different features of groundwater prospecting thematic layers

\begin{tabular}{|c|c|c|c|c|}
\hline Factor & Class & Value & Normalized weight of features & Level of Suitable \\
\hline \multirow[t]{30}{*}{ Geomorphology } & Chennai City & 2 & 0,0122 & Poor \\
\hline & Pediment & 2 & 0,0122 & Poor \\
\hline & Buried Pediment Shallow & 2 & 0,0122 & Poor \\
\hline & Buried Pediment Moderate & 3 & 0,0183 & Moderate \\
\hline & Tank & 8 & 0,0488 & Very Good \\
\hline & Buried Pediment Deep & 6 & 0,0366 & Very Good \\
\hline & Structural hill & 2 & 0,0122 & Poor \\
\hline & Valley Fill & 8 & 0,0488 & Very Good \\
\hline & River & 9 & 0,0549 & Very Good \\
\hline & Flood Plain & 9 & 0,0549 & Very Good \\
\hline & Lateritic Gravel & 3 & 0,0183 & Moderate \\
\hline & Duricrust & 2 & 0,0122 & Poor \\
\hline & Marshy Land & 7 & 0,0427 & Very Good \\
\hline & Tertiary Upland & 5 & 0,0305 & Good \\
\hline & Sand Dune & 6 & 0,0366 & Good \\
\hline & Pediment Outcrop & 2 & 0,0122 & Poor \\
\hline & Settlement & 2 & 0,0122 & Poor \\
\hline & Swales & 2 & 0,0122 & Poor \\
\hline & Beach & 5 & 0,0305 & Good \\
\hline & Paleo Deltaic Plain & 7 & 0,0427 & Very Good \\
\hline & Quartz-Graval Tertiary & 4 & 0,0244 & Moderate \\
\hline & Upper Gondwana & 8 & 0,0488 & Very Good \\
\hline & Pulicate Lake & 7 & 0,0427 & Very Good \\
\hline & Alluvial Plain & 8 & 0,0488 & Very Good \\
\hline & Laterite Tertiary & 4 & 0,0244 & Moderate \\
\hline & Creek & 5 & 0,0305 & Good \\
\hline & B Canal & 7 & 0,0427 & Very Good \\
\hline & River Island & 7 & 0,0427 & Very Good \\
\hline & Lower Gondwana & 7 & 0,0427 & Very Good \\
\hline & Dyke & 2 & 0,0122 & Poor \\
\hline
\end{tabular}




\begin{tabular}{|c|c|c|c|c|}
\hline \multirow[t]{4}{*}{ Factor } & Class & Value & Normalized weight of features & Level of Suitable \\
\hline & Gullies & 2 & 0,0122 & Poor \\
\hline & Pedi Plain & 2 & 0,0122 & Poor \\
\hline & Old River Course & 9 & 0,0549 & Very Good \\
\hline \multirow[t]{10}{*}{ Geology } & Biotite Hornblend Gnies & 4 & 0,0727 & Poor \\
\hline & Quartz Gravel & 5 & 0,0909 & Moderate \\
\hline & Sandstone Conglomarate & 5 & 0,0909 & Moderate \\
\hline & Laterite & 7 & 0,1273 & Good \\
\hline & Shale Sandstone & 5 & 0,0909 & Moderate \\
\hline & Waterbodies & 4 & 0,0727 & Poor \\
\hline & Alluvium & 8 & 0,1455 & Very Good \\
\hline & Epidote Hornblend & 5 & 0,0909 & Moderate \\
\hline & Granite & 5 & 0,0909 & Moderate \\
\hline & Charnockite & 7 & 0,1273 & Good \\
\hline \multirow[t]{3}{*}{ Drainage } & River & 8 & 0,4000 & Very Good \\
\hline & Tank/Reservoir & 9 & 0,4500 & Very Good \\
\hline & Others & 3 & 0,1500 & Poor \\
\hline \multirow[t]{3}{*}{ Water Level } & $0-6$ & 2 & 0,1429 & Poor \\
\hline & $6-11$ & 5 & 0,3571 & Moderate \\
\hline & $6-21$ & 7 & 0,5000 & Good \\
\hline \multirow[t]{10}{*}{ Soil } & Sandyloam & 3 & 0,0667 & Moderate \\
\hline & Loamysand & 3 & 0,0667 & Moderate \\
\hline & Habitation & 2 & 0,0444 & Poor \\
\hline & Waterbody & 8 & 0,1778 & Very Good \\
\hline & Sandyclayloam & 6 & 0,1333 & Good \\
\hline & Sandyclay & 6 & 0,1333 & Good \\
\hline & Clay & 3 & 0,0667 & Poor \\
\hline & Sand & 6 & 0,1333 & Good \\
\hline & Clayloam & 6 & 0,1333 & Good \\
\hline & Misce & 2 & 0,0444 & Poor \\
\hline \multirow[t]{2}{*}{ Rainfall } & $770-930$ & 1 & 0,1000 & Poor \\
\hline & $930-1090$ & 2 & 0,2000 & Moderate \\
\hline \multicolumn{2}{|c|}{ Loading [MathJax]/jax/output/CommonHTML/jax.js } & 3 & 0,3000 & Good \\
\hline
\end{tabular}




\begin{tabular}{|c|c|c|c|c|}
\hline Factor & Class & Value & Normalized weight of features & Level of Suitable \\
\hline & $1250-1410$ & 4 & 0,4000 & Very Good \\
\hline \multirow[t]{26}{*}{ Landuse } & Barren Land & 2 & 0,0211 & Poor \\
\hline & Brickiln_industries & 2 & 0,0211 & Poor \\
\hline & Beach & 3 & 0,0316 & Moderate \\
\hline & HF Ind_IT & 4 & 0,0421 & Moderate \\
\hline & Airport & 2 & 0,0211 & Poor \\
\hline & Alkalinity Salinity & 2 & 0,0211 & Poor \\
\hline & Back Water & 2 & 0,0211 & Poor \\
\hline & casurina & 3 & 0,0316 & Moderate \\
\hline & City & 2 & 0,0211 & Poor \\
\hline & Estuary & 2 & 0,0211 & Poor \\
\hline & Groves & 4 & 0,0421 & Moderate \\
\hline & Crop Land & 5 & 0,0526 & Good \\
\hline & Juliflora & 4 & 0,0421 & Moderate \\
\hline & Marshy Land & 5 & 0,0526 & Good \\
\hline & Navey & 2 & 0,0211 & Poor \\
\hline & Plantation & 5 & 0,0526 & Good \\
\hline & Pulicat Lake & 5 & 0,0526 & Good \\
\hline & River & 8 & 0,0842 & Very Good \\
\hline & Salt Pan & 2 & 0,0211 & Poor \\
\hline & Sand & 8 & 0,0842 & Very Good \\
\hline & Shrub & 5 & 0,0526 & Good \\
\hline & Waste Land & 3 & 0,0316 & Moderate \\
\hline & Landwithscrub & 4 & 0,0421 & Moderate \\
\hline & Land without Scrub & 2 & 0,0211 & Poor \\
\hline & Hills with Shrub & 2 & 0,0211 & Poor \\
\hline & Dry Crop & 7 & 0,0737 & Good \\
\hline \multirow[t]{3}{*}{ Lineament } & Buffer 500 & 6 & 0,4000 & Good \\
\hline & Buffer 750 & 8 & 0,5333 & Very Good \\
\hline & Others & 1 & 0,0667 & Poor \\
\hline Depth to Bed Rock & $11-45$ & 5 & 0,2632 & Poor \\
\hline ading [MathJax]/jax/outp & t/CommonHTML/jax.js & 6 & 0,3158 & Moderate \\
\hline
\end{tabular}




\begin{tabular}{|c|c|c|c|c|}
\hline Factor & Class & Value & Normalized weight of features & Level of Suitable \\
\hline & $75-829$ & 8 & 0,4211 & Very Good \\
\hline \multirow[t]{10}{*}{ Aspects } & Flat & 9 & 0,1957 & Very Good \\
\hline & North $0-22.5$ & 7 & 0,1522 & Very Good \\
\hline & Northeast 22.5-67.5 & 5 & 0,1087 & Good \\
\hline & East 67.5-112.5 & 6 & 0,1304 & Good \\
\hline & Southeast 112.5-157.5 & 8 & 0,1739 & Very Good \\
\hline & South $157.5-202.5$ & 4 & 0,0870 & Moderate \\
\hline & Southwest 202.5-247.5 & 3 & 0,0652 & Moderate \\
\hline & West 247.5-292.5 & 2 & 0,0435 & Poor \\
\hline & Northwest 292.5-337.5 & 1 & 0,0217 & Poor \\
\hline & North 337.5-360 & 1 & 0,0217 & Poor \\
\hline \multirow[t]{4}{*}{ Slope } & $0-2.42$ & 7 & 0,4375 & Very Good \\
\hline & $2.42-7.58$ & 4 & 0,2500 & Moderate \\
\hline & $7.58-15.61$ & 3 & 0,1875 & Moderate \\
\hline & $15.61-38.81$ & 2 & 0,1250 & Poor \\
\hline
\end{tabular}

\subsection{Groundwater potential Zones}

In this study, groundwater potential zones were identified using AHP aided methodology. The output map generated by Weighted Linear Combination (WLC) shows five different classes such as very poor, poor, moderate, good and very good potential for groundwater. The results are presented in Table 7 and the spatial variation map for the groundwater potential is shown in Fig. 14.

Table 7

Classification of Groundwater potential Zones in CRB

\begin{tabular}{|lll|}
\hline Groundwater potential class & Area $\left(\mathrm{Km}^{2}\right)$ & \% of Area \\
\hline Very Poor & 930,91 & 15,36 \\
\hline Poor & 1379,25 & 22,76 \\
\hline Moderate & 1636,20 & 27,00 \\
\hline Good & 1369,08 & 22,59 \\
\hline Very Good & 743,89 & 12,28 \\
\hline
\end{tabular}

The groundwater potential is very poor in the western regions especially the northwestern region and the coastal region of the Chennai and Kancheepuram area. It is $15.4 \%$ of the total area with a land area of $930.9 \mathrm{~km}^{2}$. Geologically, the western region is mostly Charnockite formation, and the coastal region is alluvium deposits. It is obvious that the massive Charnockite is not a good aquifer unless there are factures or joints. In general alluviums have good water bearina capacitv, but the potential is showing low in the analysis. This can be explained by the over-exploited aquifer Loading [MathJax]/jax/output/CommonHTML/jax.js 
system, especially in the South Chennai coastal aquifer. Increased urbanization and population growth directly affect the groundwater potential of these regions. These results agree with the land use map of the study area. There are many barren lands in the western region, and this is also a reason for the poor potential of this area. The second classification of groundwater potential was "poor", it is also located mostly in the same geographic regions of the very poor category and possess the same geological and geomorphological characteristics. This category is second largest among the five classes, with a share of $22.86 \%$ spread over $1379.2 \mathrm{~km}^{2}$ in the CRB. Moderate potential zones are dominant among all classes with an area of $1636 \mathrm{Km}^{2}, 27 \%$ of the total land area of the CRB. Moderate potential is observed throughout the basin, however, it is largely located in the SE and NE regions, as well as the central part. The major geology for this group is alluvium, coastal alluvium, and Charnockite formations. There is a patch in the middle area of the basin extending north from Gummidipoondi in the Thiruvallur district to south in Kaveripakkam in the Vellore district which has good and very good groundwater potential. This includes some bordering portions of the Chennai district as well. Both these classes together constitute $34 \%$ of the study area and spread over $2100 \mathrm{~km}^{2}$. This area is mostly covered by alluvial formations resulting from the river system and its deposits.

Table 7: Classification of Groundwater potential Zones in CRB

Figure 14: Spatial variation map of Groundwater potential in CRB

\subsection{Cross verification of the Groundwater potential zones with Bore hole data}

The groundwater potential map is created based on the available maps of different factors using GIS based AHP method. However, it is necessary to verify the results using actual data collected from the field. This study used 51 bore holes, in which the specific capacity was compared with the groundwater potential mapped using GIS based method. The Yield data from the field is classified into low yield ( $<3$ lps), moderate yield ( $3-6 \mathrm{lps})$ and high yield ( $>6 \mathrm{lps})$. The details of the procedure and the results of the comparison are provided in Table 8. 
Table 8

Comparison of Groundwater potential zones with actual field data

\begin{tabular}{|c|c|c|c|c|c|c|}
\hline Location name & $x$ & $Y$ & $\begin{array}{l}\text { Actual Specific } \\
\text { Capacity }\end{array}$ & $\begin{array}{l}\text { Interference on } \\
\text { actual yield }\end{array}$ & $\begin{array}{l}\text { Expected yield } \\
\text { from map }\end{array}$ & $\begin{array}{l}\text { Suitability } \\
\text { Agreement }\end{array}$ \\
\hline Velachery & 80,23 & 12,98 & 2,71 & Low & Low to moderate & Agree \\
\hline Ayyanavaram & 80,23 & 13,10 & 4 & Moderate & moderate & Agree \\
\hline Tandiarpet & 80,28 & 13,13 & 0,61 & Low & Very low to low & Agree \\
\hline Mandaiveli & 80,25 & 13,01 & 0,56 & low & Very low to low & Agree \\
\hline Besent Nagar & 80,27 & 13,00 & 12 & high & $\begin{array}{l}\text { Moderate to } \\
\text { high }\end{array}$ & Agree \\
\hline Arumbakkam & 80,21 & 13,07 & 3,47 & Moderate & Very low to low & disagree \\
\hline Redhills & 80,19 & 13,19 & 1 & low & Moderate & disagree \\
\hline Tirumalisai & 80,06 & 13,05 & 1,5 & low & Moderate & disagree \\
\hline Pallavaram & 80,15 & 12,97 & 2,11 & low & Low to moderate & Agree \\
\hline Pallikaranai & 80,20 & 12,94 & 3,11 & Moderate & Low to moderate & Agree \\
\hline Solinganallur & 80,23 & 12,90 & 4,66 & Moderate & Low to moderate & Agree \\
\hline Alathur & 80,18 & 12,69 & 2,28 & low & low to moderate & Agree \\
\hline Sembakkam & 80,13 & 12,71 & 2,9 & low & $\begin{array}{l}\text { poor to } \\
\text { moderate }\end{array}$ & agree \\
\hline Thaiyur & 80,20 & 12,78 & 1,5 & low & Low to moderate & Agree \\
\hline Ottivakkam & 80,12 & 12,70 & 2,5 & low & Low to moderate & Agree \\
\hline Melakottaiyur & 80,15 & 12,84 & 2,11 & low & Very low to low & Agree \\
\hline Madampakkam & 80,05 & 12,83 & 1,9 & low & Very low to low & Agree \\
\hline Ponmar & 80,17 & 12,84 & 4,1 & Moderate & moderate & Agree \\
\hline Padappai & 80,03 & 12,88 & 1,42 & low & Very low to low & Agree \\
\hline Sriperumbadur & 79,94 & 12,95 & 1,82 & low & $\begin{array}{l}\text { Good to very } \\
\text { good }\end{array}$ & disagree \\
\hline Purisai & 79,75 & 12,99 & 2,24 & low & $\begin{array}{l}\text { moderate to } \\
\text { high }\end{array}$ & disagree \\
\hline Kunrathur & 80,10 & 13,00 & 5,47 & Moderate & $\begin{array}{l}\text { Moderate to } \\
\text { high }\end{array}$ & Agree \\
\hline Thandalam & 80,00 & 13,10 & 3 & Moderate & $\begin{array}{l}\text { Moderate to } \\
\text { high }\end{array}$ & Agree \\
\hline Ambattur & 80,15 & 13,11 & 2,37 & low & low & Agree \\
\hline Arani & 80,09 & 13,33 & 3,3 & Moderate & Moderate & agree \\
\hline Avadi & 80,10 & 13,12 & 2,4 & low & Low to moderate & agree \\
\hline Ennore & 80.24 & 13.22 & 1.9 & low & Low to moderate & Agree \\
\hline
\end{tabular}




\begin{tabular}{|c|c|c|c|c|c|c|}
\hline Location name & $x$ & $\mathbf{Y}$ & $\begin{array}{l}\text { Actual Specific } \\
\text { Capacity }\end{array}$ & $\begin{array}{l}\text { Interference on } \\
\text { actual yield }\end{array}$ & $\begin{array}{l}\text { Expected yield } \\
\text { from map }\end{array}$ & $\begin{array}{l}\text { Suitability } \\
\text { Agreement }\end{array}$ \\
\hline Gummidipoondi & 80,13 & 13,40 & 1,12 & low & moderate & disagree \\
\hline Kaverirajapuram & 79,75 & 13,17 & 2 & low & Low to moderate & Agree \\
\hline Korattur & 80,01 & 13,08 & 4,5 & Moderate & $\begin{array}{l}\text { Moderate to } \\
\text { high }\end{array}$ & Agree \\
\hline Madhavaram & 80,23 & 13,15 & 3,16 & Moderate & Low to moderate & Agree \\
\hline Nabalur & 79,70 & 13,20 & 3,02 & Moderate & $\begin{array}{l}\text { poor to } \\
\text { moderate }\end{array}$ & Agree \\
\hline Nandiambakkam & 80,28 & 13,27 & 7,41 & high & $\begin{array}{l}\text { poor to } \\
\text { moderate }\end{array}$ & disagree \\
\hline Pallipattu & 79,44 & 13,34 & 2,8 & Low & Low to moderate & agree \\
\hline Pazhverkadu & 80,33 & 13,42 & 5,02 & Moderate & $\begin{array}{l}\text { moderate to } \\
\text { good }\end{array}$ & Agree \\
\hline Pondeswaram & 80,07 & 13,19 & 4,75 & high & $\begin{array}{l}\text { moderate to } \\
\text { good }\end{array}$ & agree \\
\hline Red Hills & 80,18 & 13,19 & 2,47 & Low & $\begin{array}{l}\text { moderate to } \\
\text { good }\end{array}$ & agree \\
\hline Thandarai & 80,06 & 13,11 & 2,4 & Low & Low to moderate & agree \\
\hline Thervoy & 79,92 & 13,37 & 3,01 & Moderate & Low to moderate & Agree \\
\hline Thirumullaivoyal & 80,13 & 13,13 & 2,26 & Low & Low to moderate & Agree \\
\hline Tiruthani(taluk) & 79,61 & 13,18 & 3,14 & Moderate & Low to moderate & agree \\
\hline Tiruvotriyur & 80,30 & 13,15 & 2,11 & Low & moderate & disagree \\
\hline Uthukkottai & 79,90 & 13,33 & 3 & Moderate & Low to moderate & Agree \\
\hline Veppampattu & 79,98 & 13,13 & 3,66 & Moderate & $\begin{array}{l}\text { moderate to } \\
\text { good }\end{array}$ & Agree \\
\hline Arakkonam & 79,67 & 13,08 & 4,3 & Moderate & Low to moderate & disagree \\
\hline RK Pet & 79,44 & 13,17 & 2,7 & Low & Low & Agree \\
\hline Panapakkam & 79,57 & 12,92 & 3,23 & Moderate & Low to moderate & Agree \\
\hline Sumaithangi & 79,44 & 12,90 & 4,34 & Moderate & $\begin{array}{l}\text { moderate to } \\
\text { good }\end{array}$ & Agree \\
\hline Kunnattur & 79,53 & 13,06 & 4,81 & Moderate & low & disagree \\
\hline Sholingur & 79,42 & 13,11 & 3,6 & Moderate & low & disagree \\
\hline
\end{tabular}

The accuracy calculations were done as follows:

- Number of boreholes $=51$

- Number of boreholes agreed with the result of mapping $=40$

- Number of horeholes disaareed with the result of mapping = 11

Loading [MathJax]/jax/output/CommonHTML/jax.js 
- Accuracy of the potential mapping $=40 / 51 \times 100=78.43 \%$

This suggests that among the 51 wells, the prediction was reliable in 40 wells. This means that $78 \%$ of the potential delineation agreed with the actual data from the field. The use of AHP based groundwater potential zonation thus proved to be successful and can be adopted as a cost-effective groundwater prospecting method.

Table 8: Comparison of Groundwater potential zones with actual field data

\section{Conclusions}

This study used GIS, remote sensing, multi-criteria decision-making techniques, and analytical hierarchy process (AHP) for the delineation of groundwater potential zones in the Chennai River Basin (CRB). 11 different thematic layers that has direct influence on groundwater potential were used in this study and the weights were given using AHP methodology. The resultant thematic layers were merged using overlay analysis and the groundwater potential maps were generated. According to these maps, 35\% of the study area has good to very good groundwater potential, $27 \%$ has moderate potential and $38 \%$ has poor to very poor groundwater potential. Groundwater in the coastal region and the urban area shows very poor potential and the high potential is observed in the central regions. The resultant potential map was compared with the bore hole discharge data collected from the field. The specific capacity of the wells was used for comparing the potential. This analysis shows that more than $78 \%$ of the field data is matched with the predicted map. This suggests that the method has greater accuracy in mapping the groundwater potential zones with comparatively less cost.

\section{References}

Agarwal R, Garg PK (2016) Remote Sensing and GIS Based Groundwater Potential \& Recharge Zones Mapping Using Multi-Criteria Decision Making Technique. Water Resources Management 30 (1):243-260

Al-Saady Y, Al-Suhail QA, Al-Tawash BS, Othman AA (2016) Drainage network extraction and morphometric analysis using remote sensing and GIS mapping techniques (Lesser Zab River Basin, Iraq and Iran). Environmental Earth Sciences: $2016,75: 1243$

Andreas N. Angelakis Konstantinos S. Voudouris, llias Mariolakos (2016) Groundwater utilization through the centuries focusing on the Hellenic civilizations. Hydrogeology Journal 24(5):1311-1324.

Bhola PK, Zabel AK, Rajaveni SP, Indu, SN, Monninkhoff B, Elango L (2013) Integrated surface water and groundwater modeling for optimizing MAR structures in the Chennai region. In: 8th Annual International Symposium on Managed Aquifer Recharge - ISMAR8. Beijing.

CGWB (2008) District Groundwater Brochure Chennai District Tamil Nadu. Technical report series

Charalambous AN and Garratt P (2009) Recharge-abstraction relationships and sustainable yield in the AraniKortalaiyar groundwater basin, India. Quarterly Journal of Engineering Geology and Hydrogeology 42 (1): $39-50$.

Das N, Mukhopadhyay S (2018) Application of multi-criteria decision-making technique for the assessment of groundwater potential zones: a study on Birbhum district, West Bengal, India Environment, Development and Sustainability. https://doi.org/10.1007/s10668-018-0227-7

Dhawan V (2017) Water and Agriculture in India Background paper for the South Asia expert panel during the Global Loading [MathJax]/jax/output/CommonHTML/jax.js erail Ministry of Food and Agriculture (BMEL) pages 1- 
Elango L and Manickam S 1986 Groundwater quality of Madras aquifer: A study on Panjetti-Ponneri-Minjur area; Indian Geol. J. 61 41-49

Elbeih SF (2014) An overview of integrated remote sensing and GIS for groundwater mapping in Egypt. Ain Shams Engineering Journal 6 (1) 1-15

FAO: AQUASTAT - FAO's global information system on water and agriculture, FAO, http://www.fao.org/nr/aquastat, last access: 16 March 2010, Rome, Italy, 2010

Hadley, R. F. (1961), Some effects of microclimate on slope morphology and drainage basin development, in Geological Survey Research 1961, edited by Department of the Interior United States Geological Survey, pp. B32-B34, Gov. Print. Off., Washington, D. C.

Freeze RA, Cherry J (1979) Groundwater. Prentice-Hall, Hoboken, NJ

Jennifer MA, Arul C (2012) Groundwater Management-A Policy Perspective. World Academy of Science, Engineering and Technology International Journal of Geological and Environmental Engineering Vol:6, No:2, pages 1-8.

Nair S , Rajaveni S P , Schneider M and Elango L (2015) Geochemical and isotopic signatures for the identification of seawater intrusion in an alluvial aquifer. J. Earth Syst. Sci. 124( 6):1281-1291

Elango L, Ramachandran S, Chowdary YSN (1992) Groundwater quality in coastal regions of South Madras. Ind J Environ Health 34:318- 325

Magesh NS, Chandrasekar N, Soundranayagam JP (2011) Delineation of groundwater potential zones in Theni district, Tamil Nadu, using remote sensing, GIS and MIF techniques. Geoscience Frontiers 3(2): 189-196

Murthy KSR, Amminedu E, Rao VV (2003) Integration of Thematic Maps Through GIS for Identification of Groundwater Potential Zones. Journal of the Indian Society of Remote Sensing 31(3) 197-210.

Nag SK, Ghosh P (2013) Delineation of groundwater potential zone in Chhatna Block, Bankura District, West Bengal, India using remote sensing and GIS techniques. Environmental Earth Sciences70(5) 2115-212.

Nagaraju D, Papanna C, Siddalingamurthy S. Mahadevaswamy G, Lakshmamma, Lone, MS, Nagesh, PC, Rao K (2011) Identification of groundwater potential zones through remote sensing and gis techniques in Kollegal taluk, Chamarajnagar District, Karnataka, India. International Journal of Earth Sciences and Engineering, 4 (4): 651-658.

Prasad RK, Mondal NC, Banerjee P, Nandakumar MV, Singh VS (2008) Deciphering potential groundwater zone in hard rock through the application of GIS. Environmental Geology 55:467-475

Rahmati O, Nazari Samani A, Mahdavi M, Pourghasemi, HR, Zeinivand H (2015) Groundwater potential mapping at Kurdistan region of Iran using analytic hierarchy process and GIS. Arabian Journal of Geosciences, 8(9): 7059-7071

Raicy MC, Elango L (2017) Percolation pond as a method of managed aquifer recharge in a coastal saline aquifer: a case study on the criteria for site selection and its impacts. J Earth Syst Sci 126:1- 16

Sathish S, Elango L, Rajesh R, Sarma VS (2011) Assessment of seawater mixing in a coastal aquifer by high resolution electrical resistivitv tomoaraphv. Int J Environ Sci Technol 8:483-492

Loading [MathJax]/jax/output/CommonHTML/jax.js

Page 19/33 
Singh A, Panda SN, Kumar KS, Sharma CS (2013) Artificial Groundwater Recharge Zones Mapping Using Remote Sensing and GIS: A Case Study in Indian Punjab. Environmental Management 52:61-71

Suganthi S, Elango L, Subramanian S K (2013) Groundwater potential zonation by Remote Sensing and GIS techniques and its relation to the Groundwater level in the Coastal part of the Arani and Koratalai River Basin, Southern India. Earth Sciences Research Journal 17(2)87 - 95.

Saaty TL (1980) The analytic hierarchy process: planning, priority setting, resource allocation. McGraw-Hill, New York

\section{Figures}

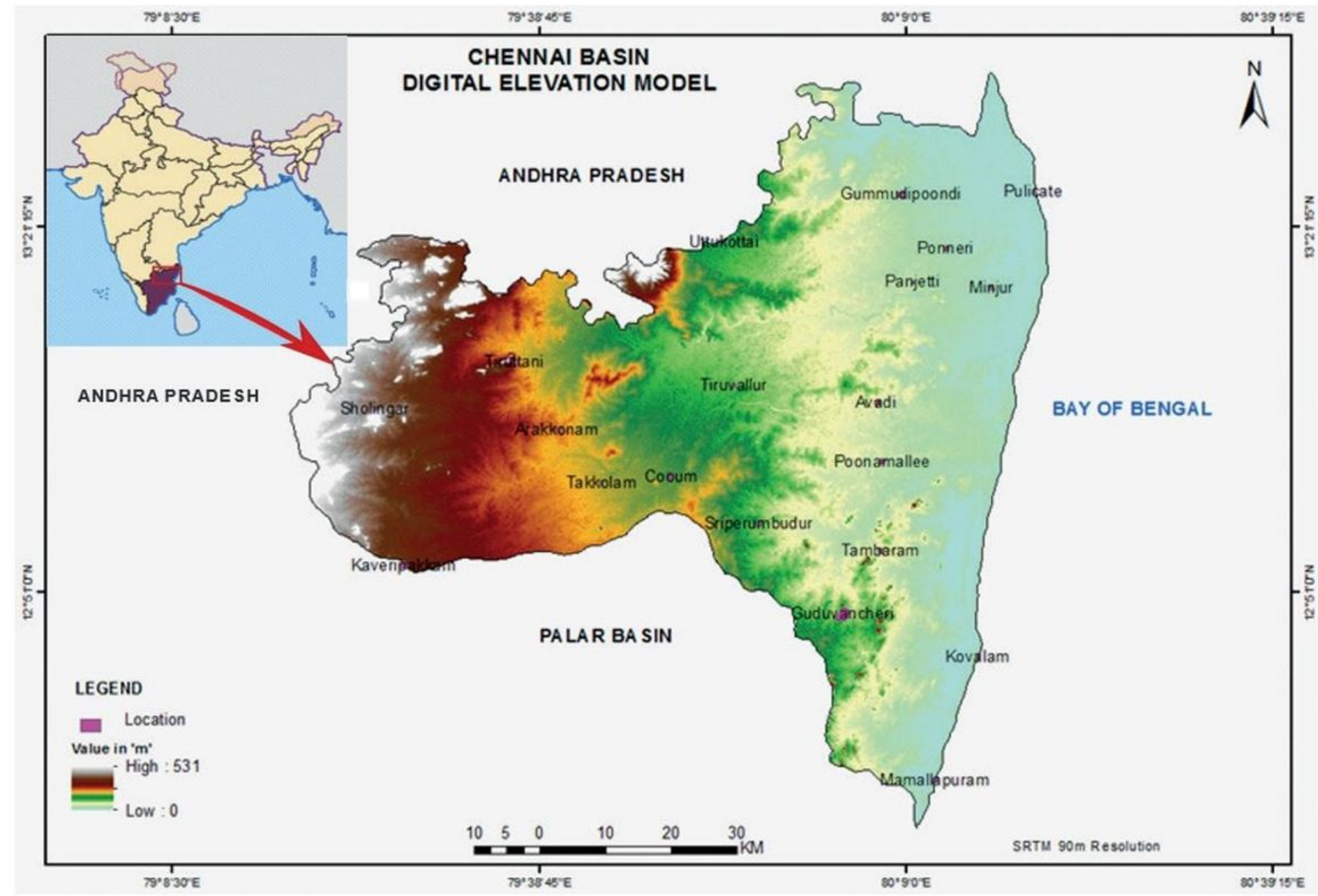

Figure 1

Location map of the study area 


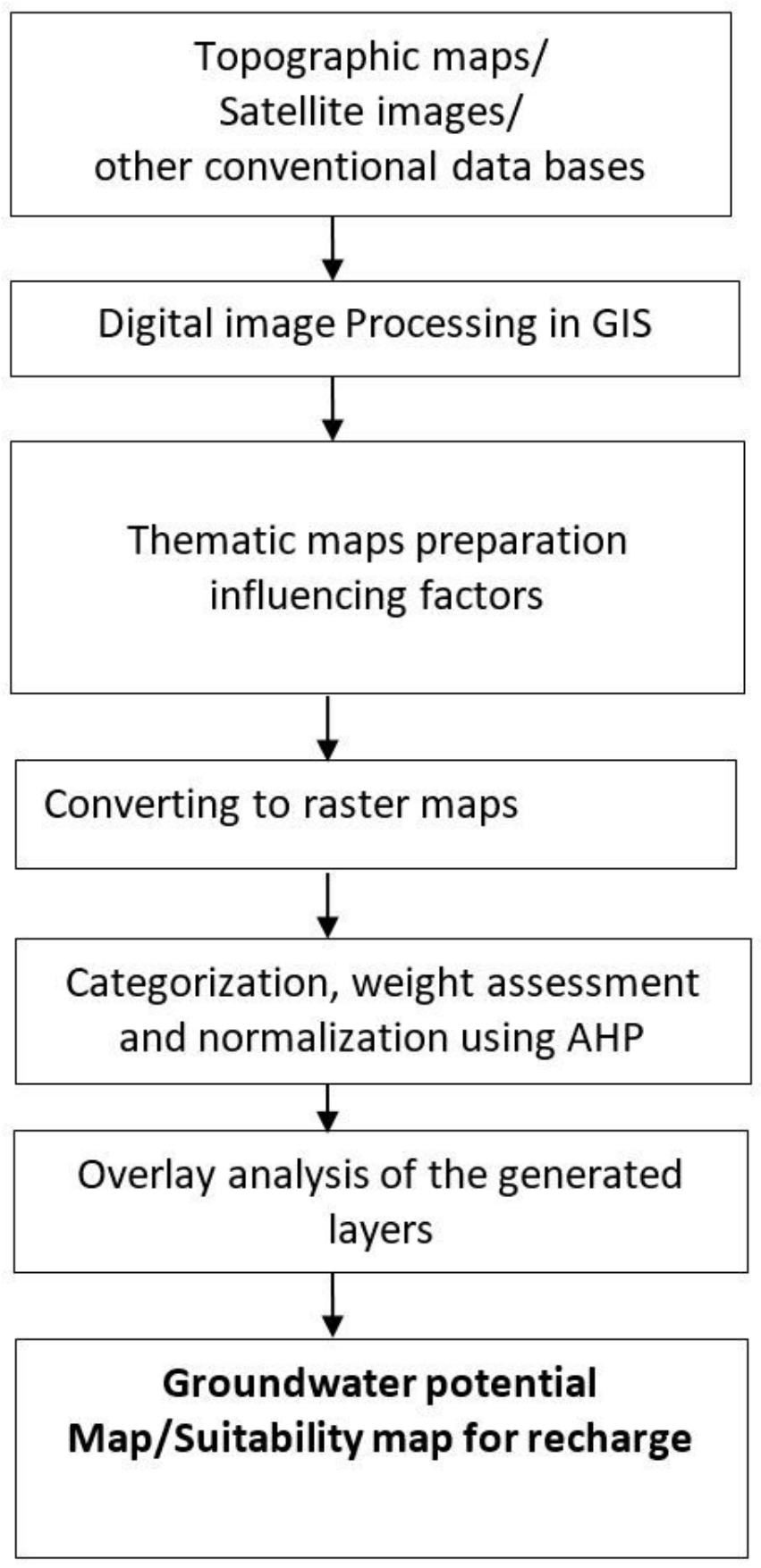

Figure 2

Flow chart showing the methodology adopted in the study 


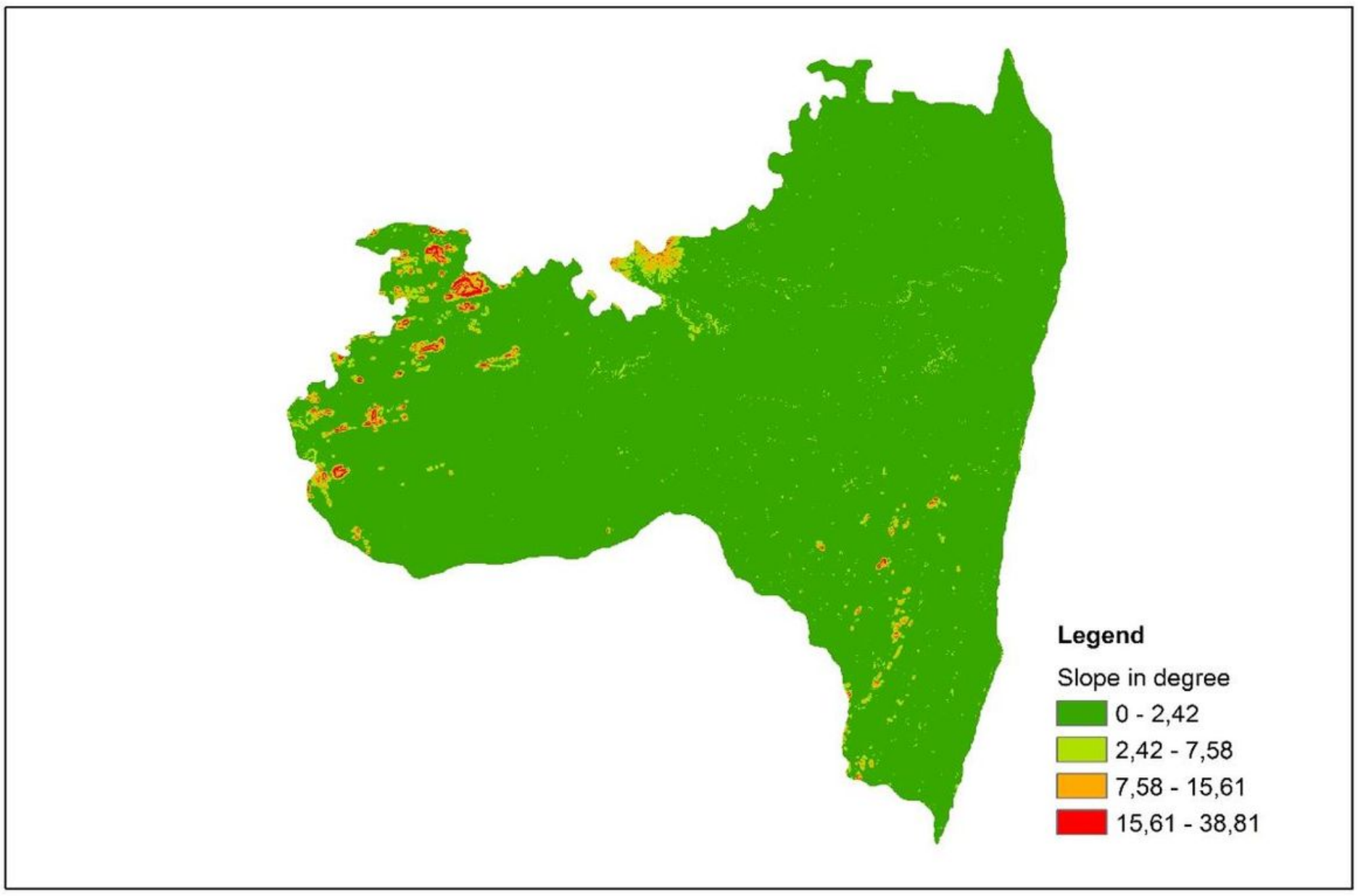

Figure 3

Slope Map 


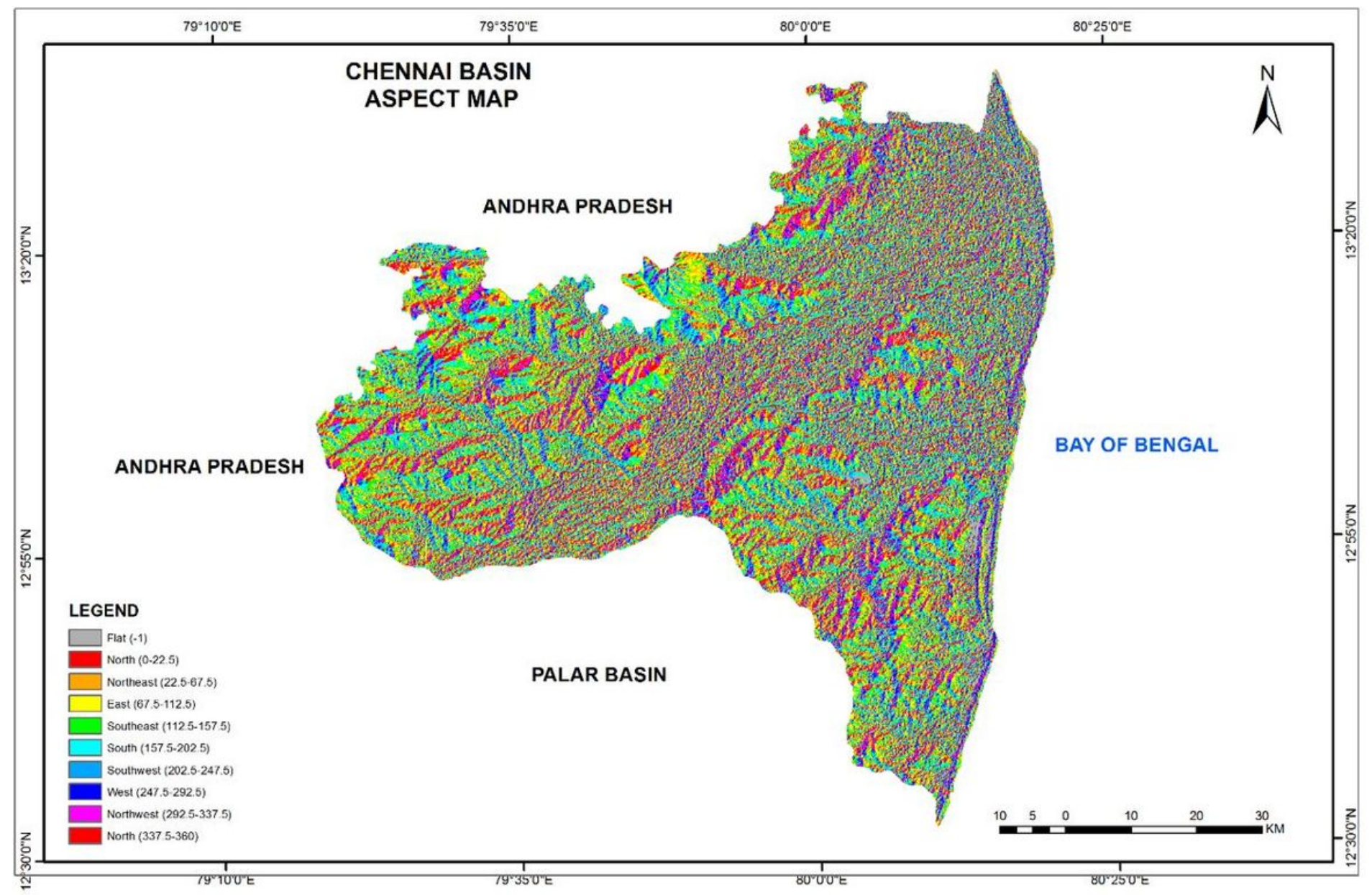

Figure 4

Aspect Map 


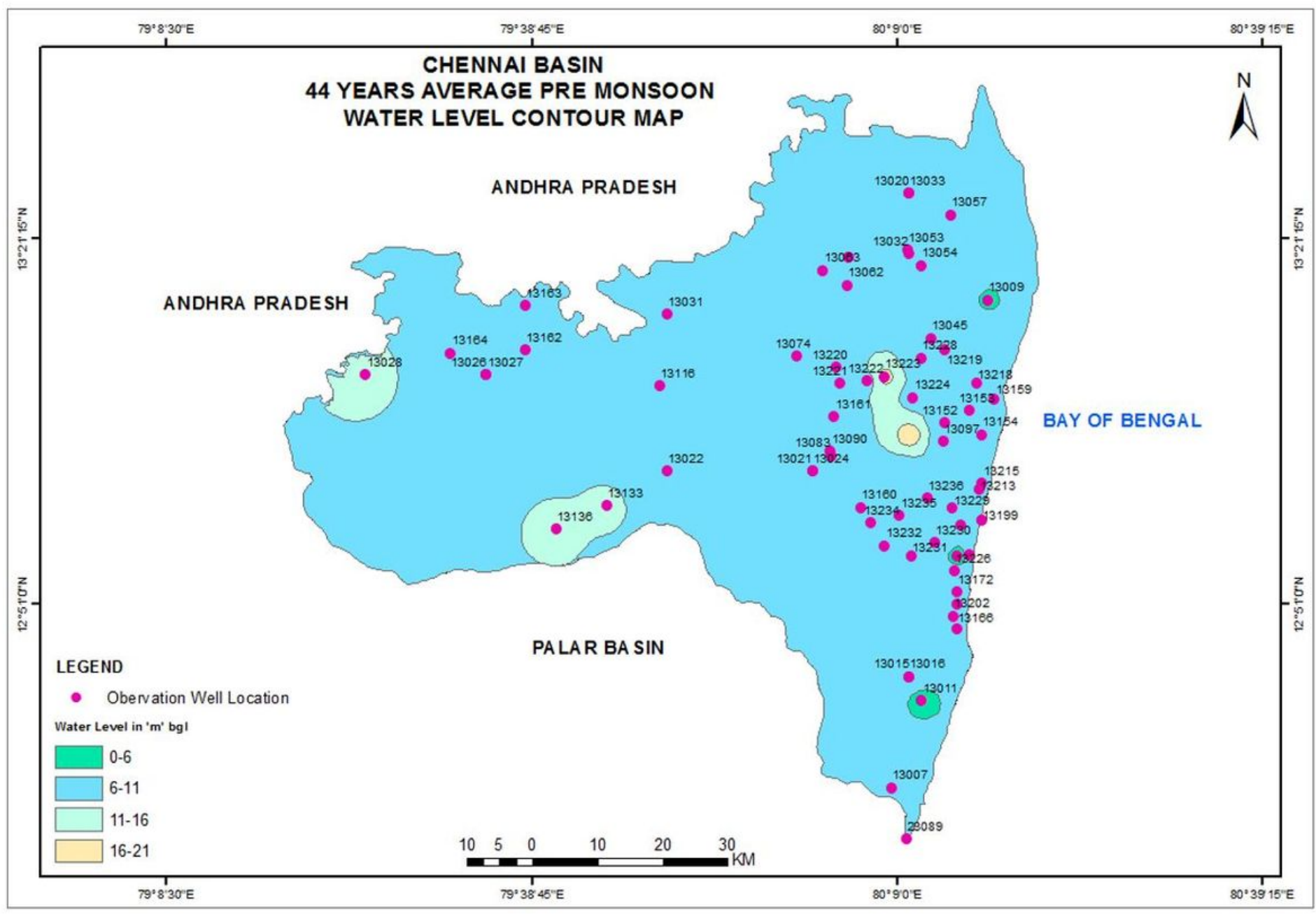

Figure 5

Groundwater Level Map 


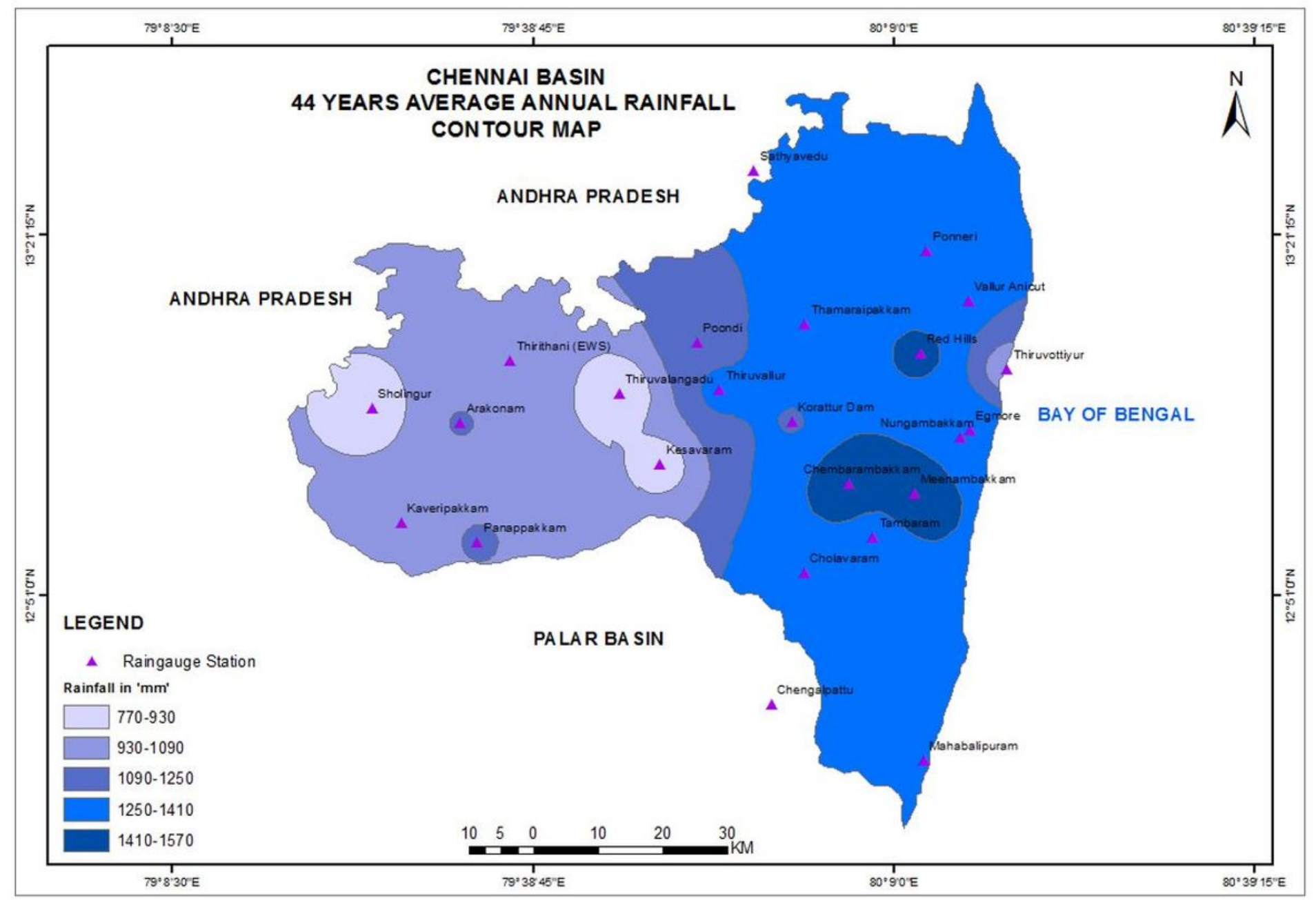

Figure 6

Rainfall map 


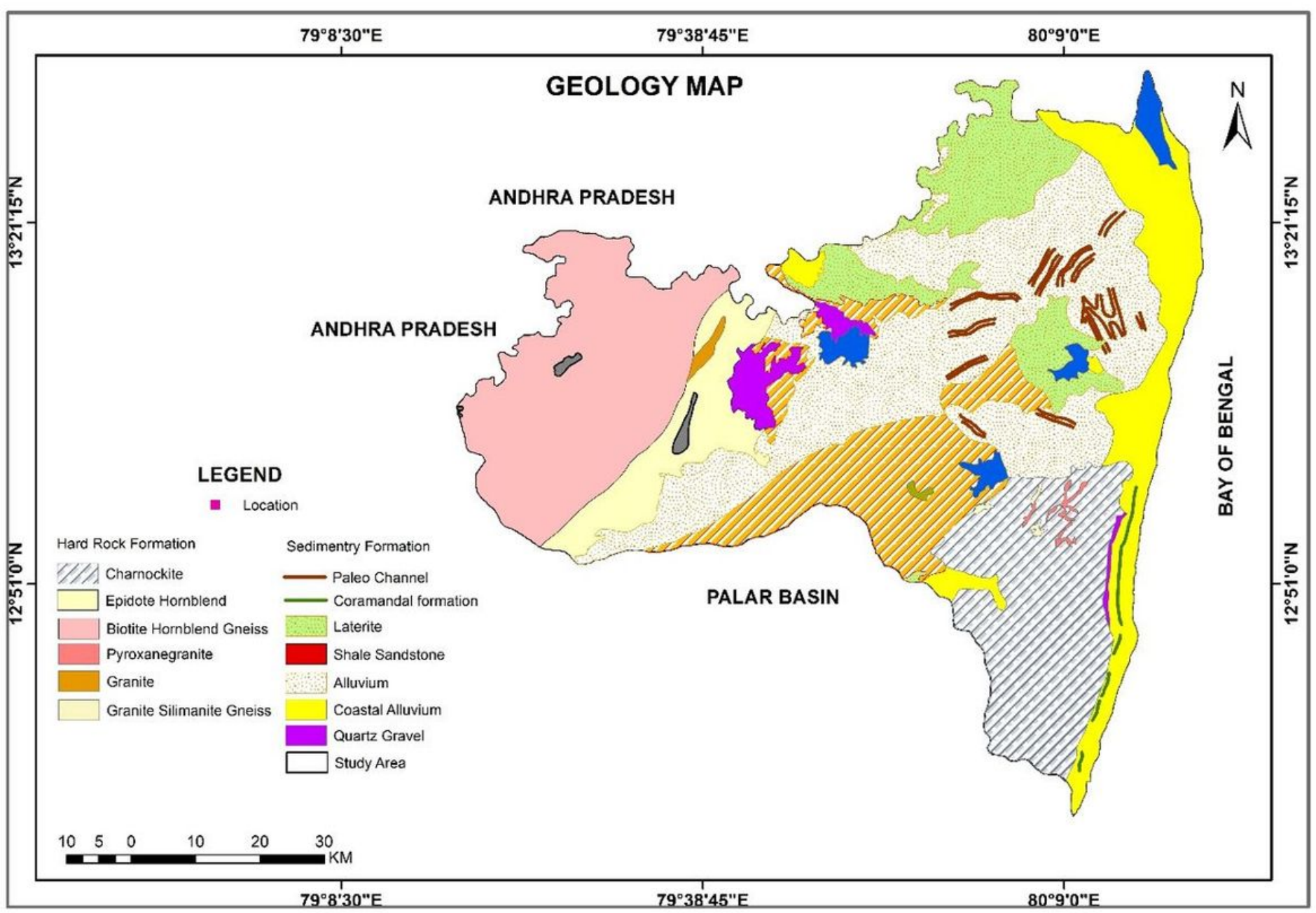

Figure 7

Geological of the study area 


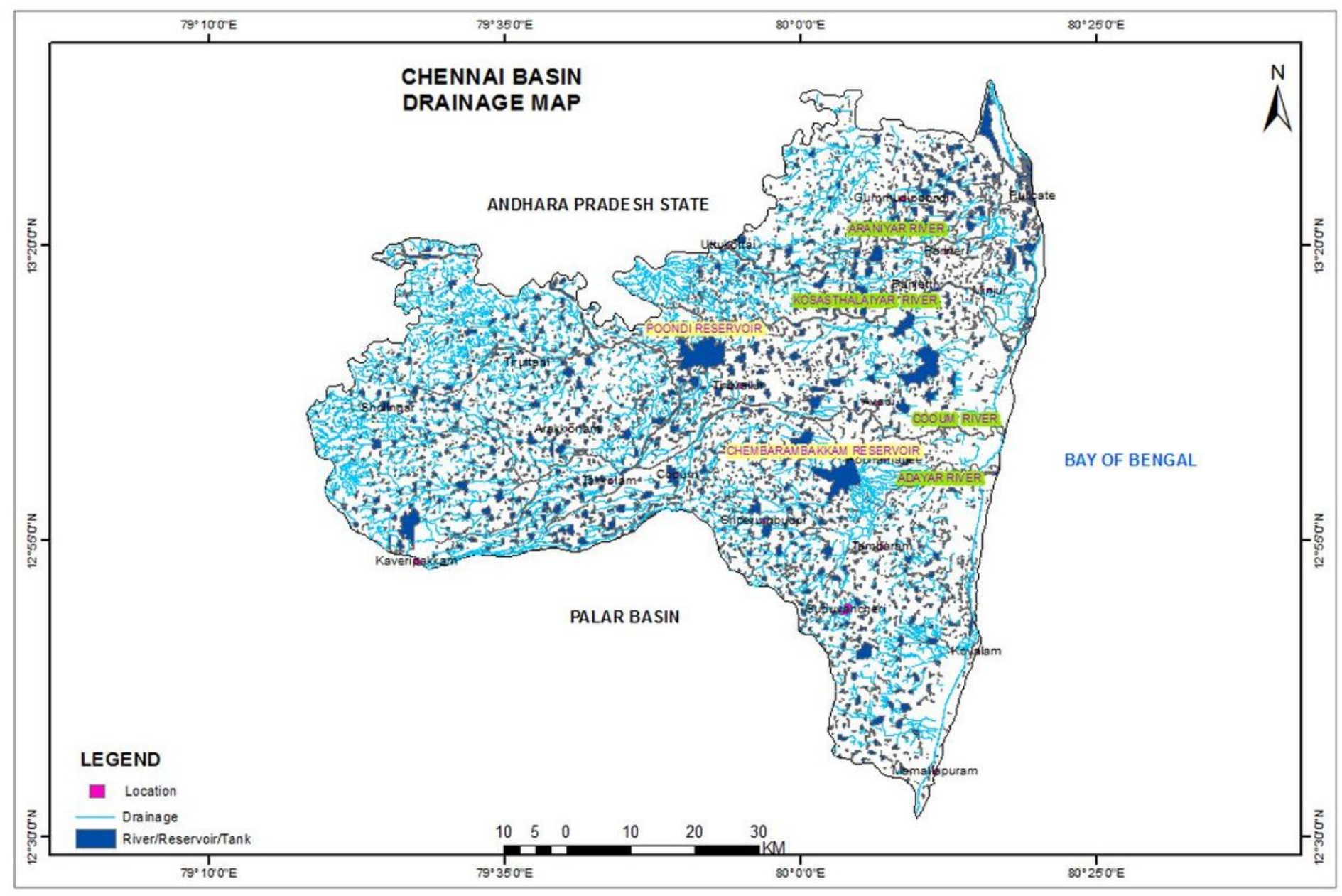

Figure 8

Drainage Map 


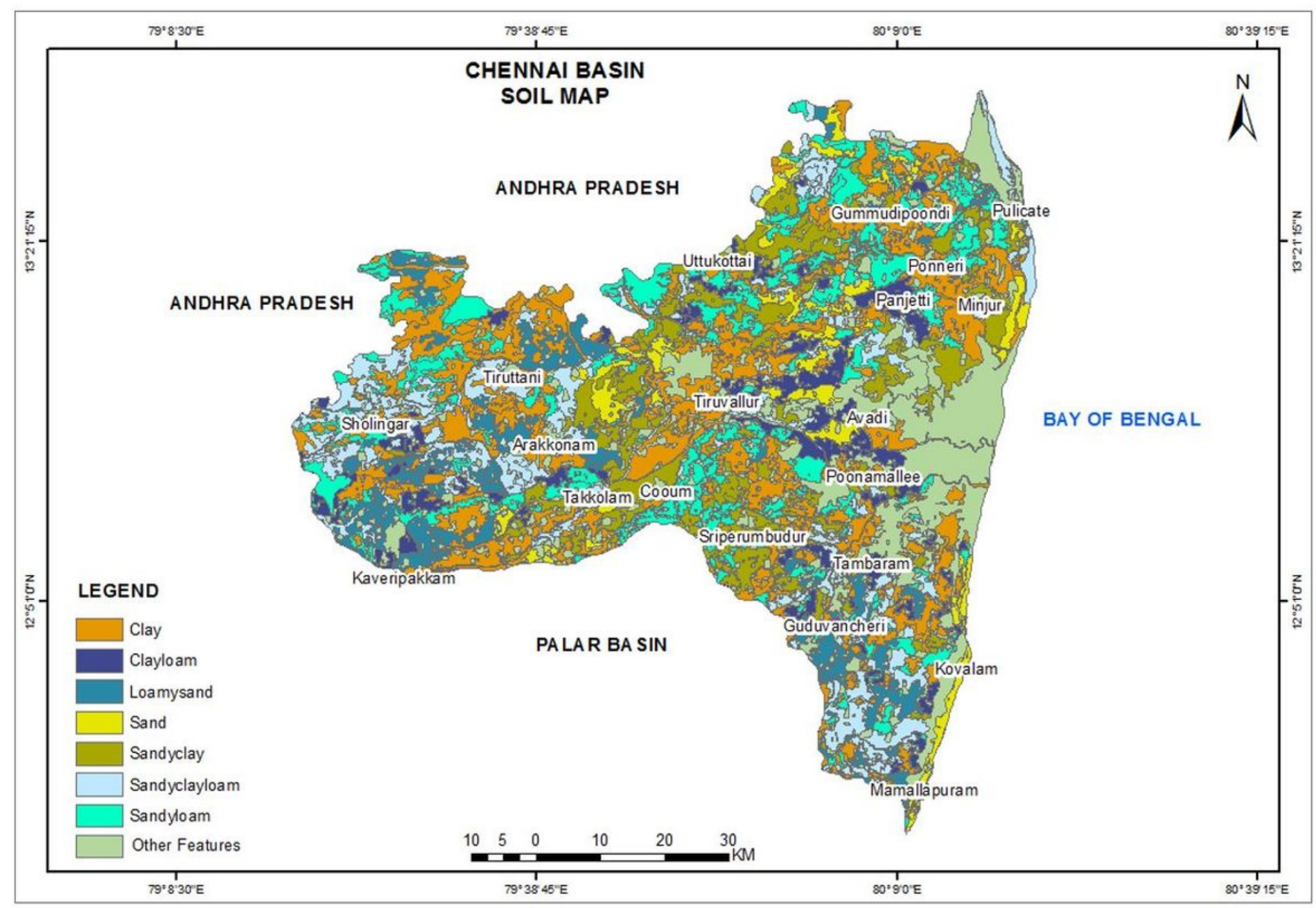

Figure 9

Soil map 


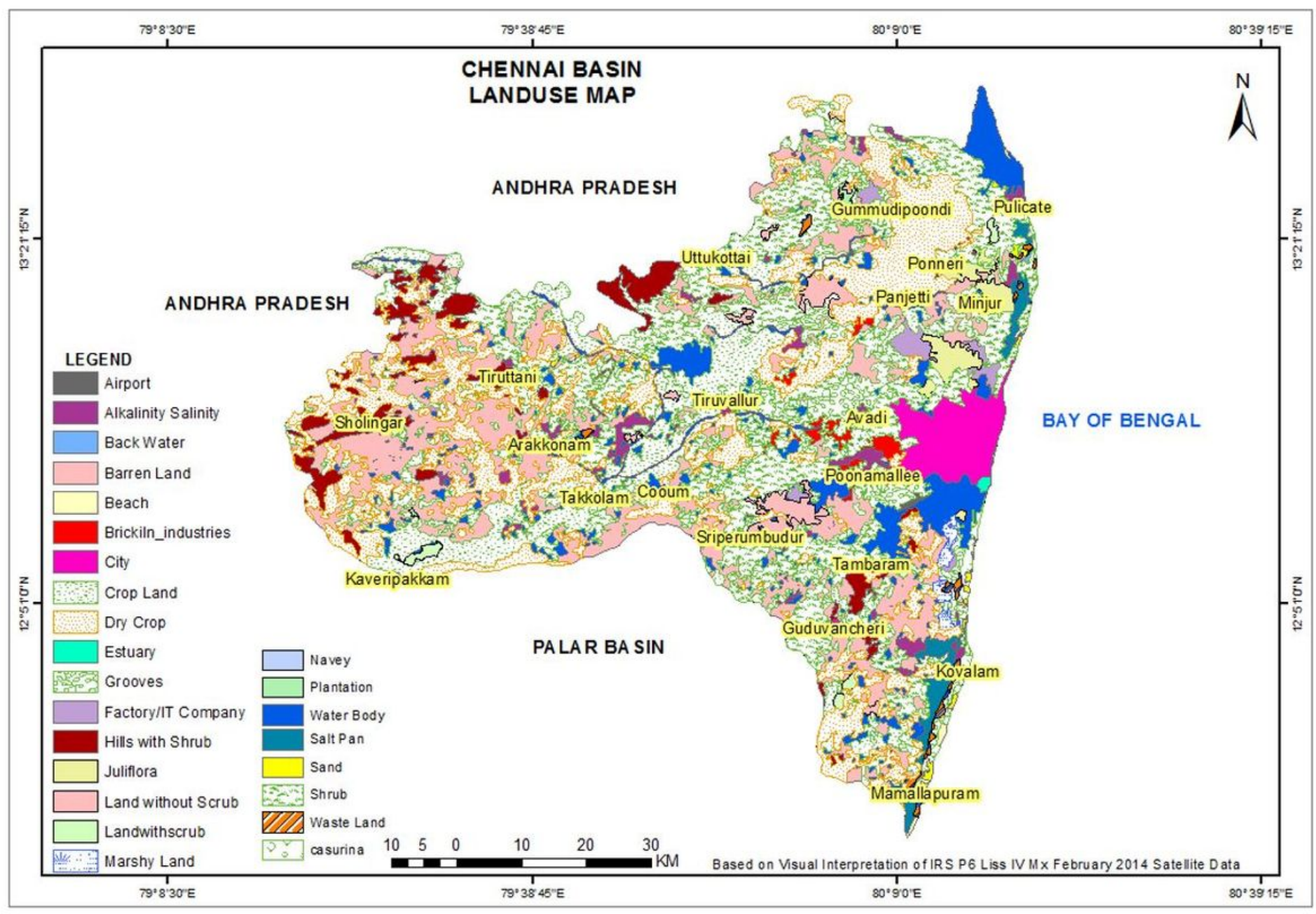

Figure 10

Land-use map of Chennai Basin 


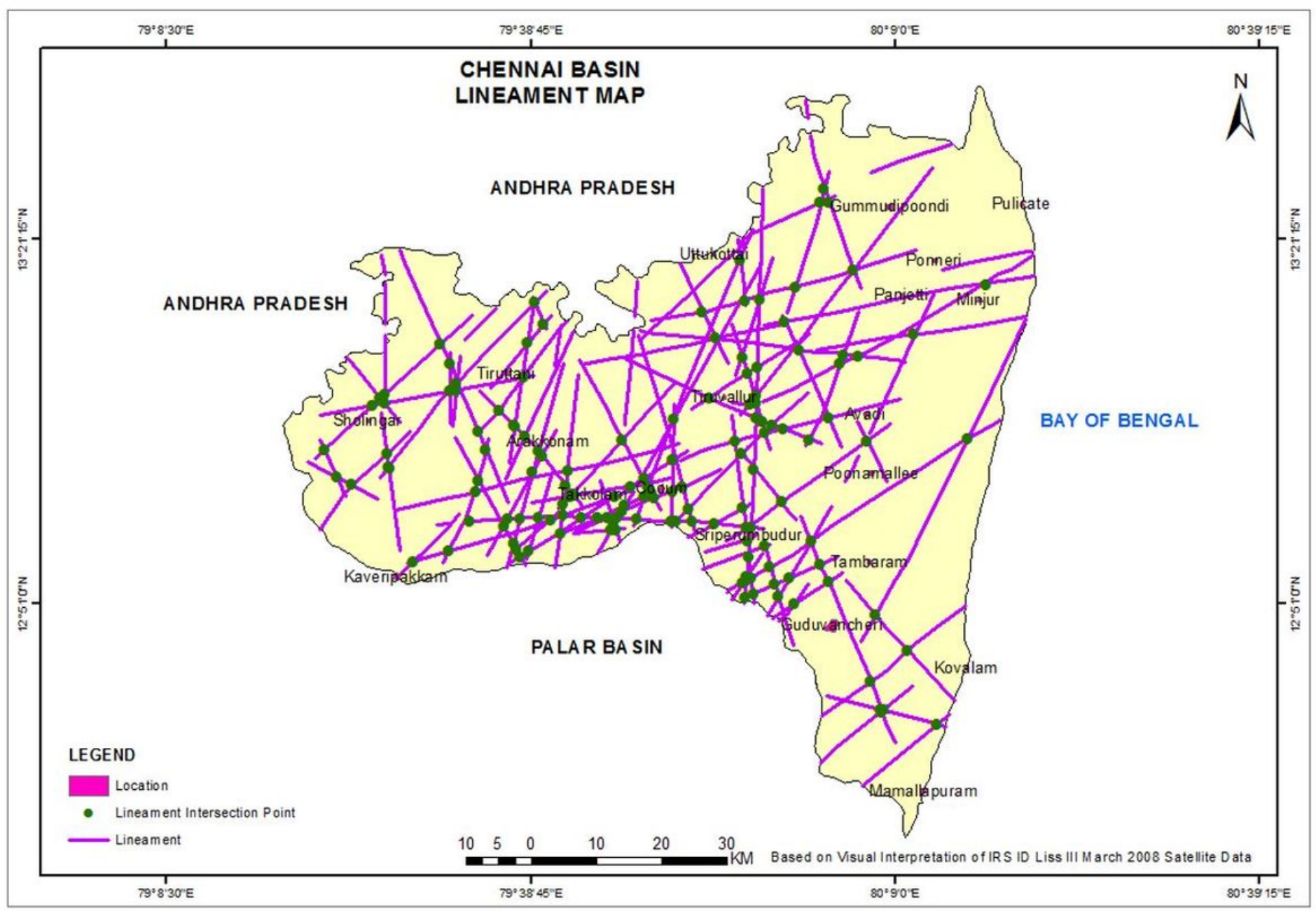

Figure 11

Lineaments Map 


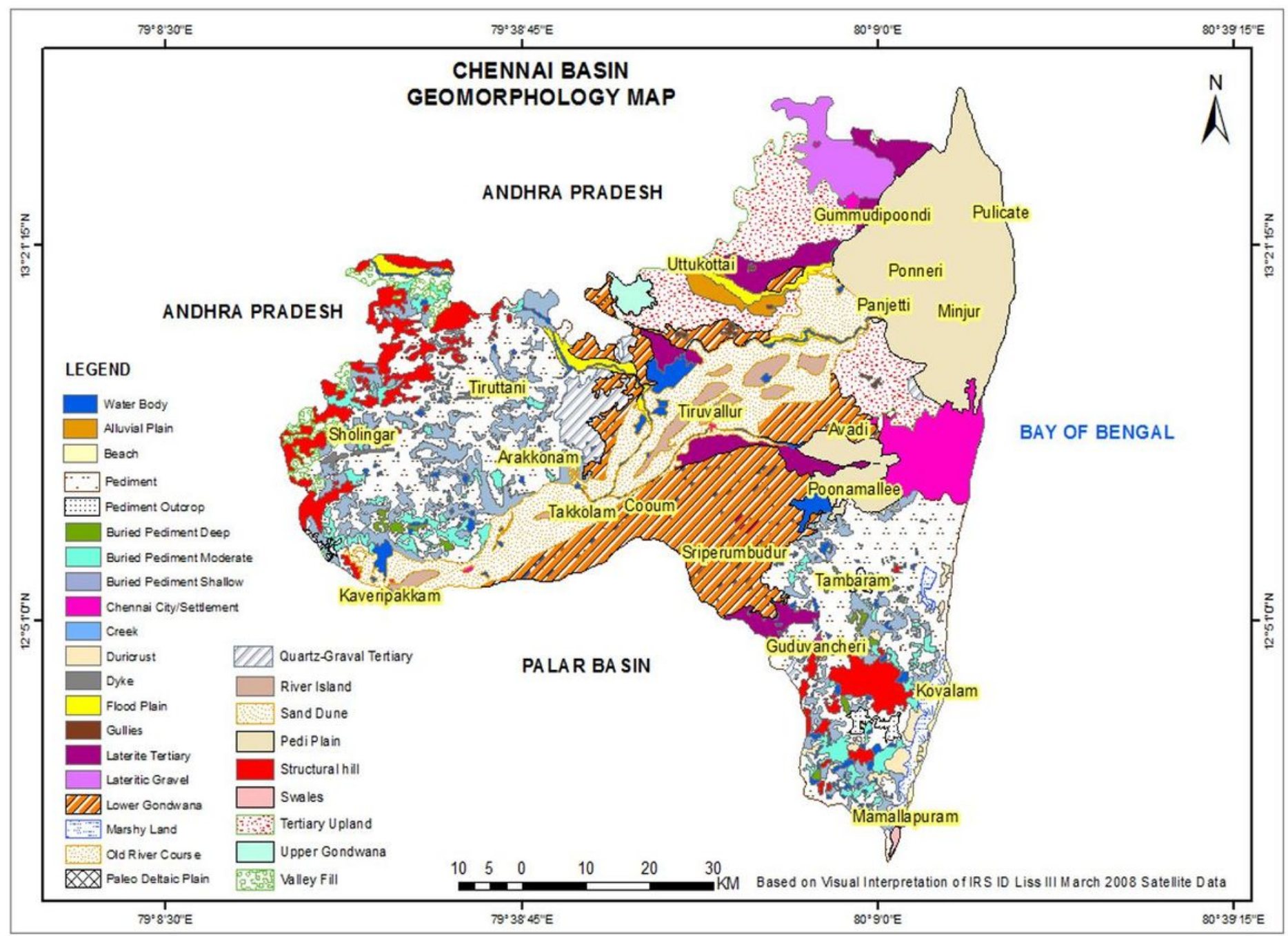

Figure 12

Geomorphology map of the study area. 


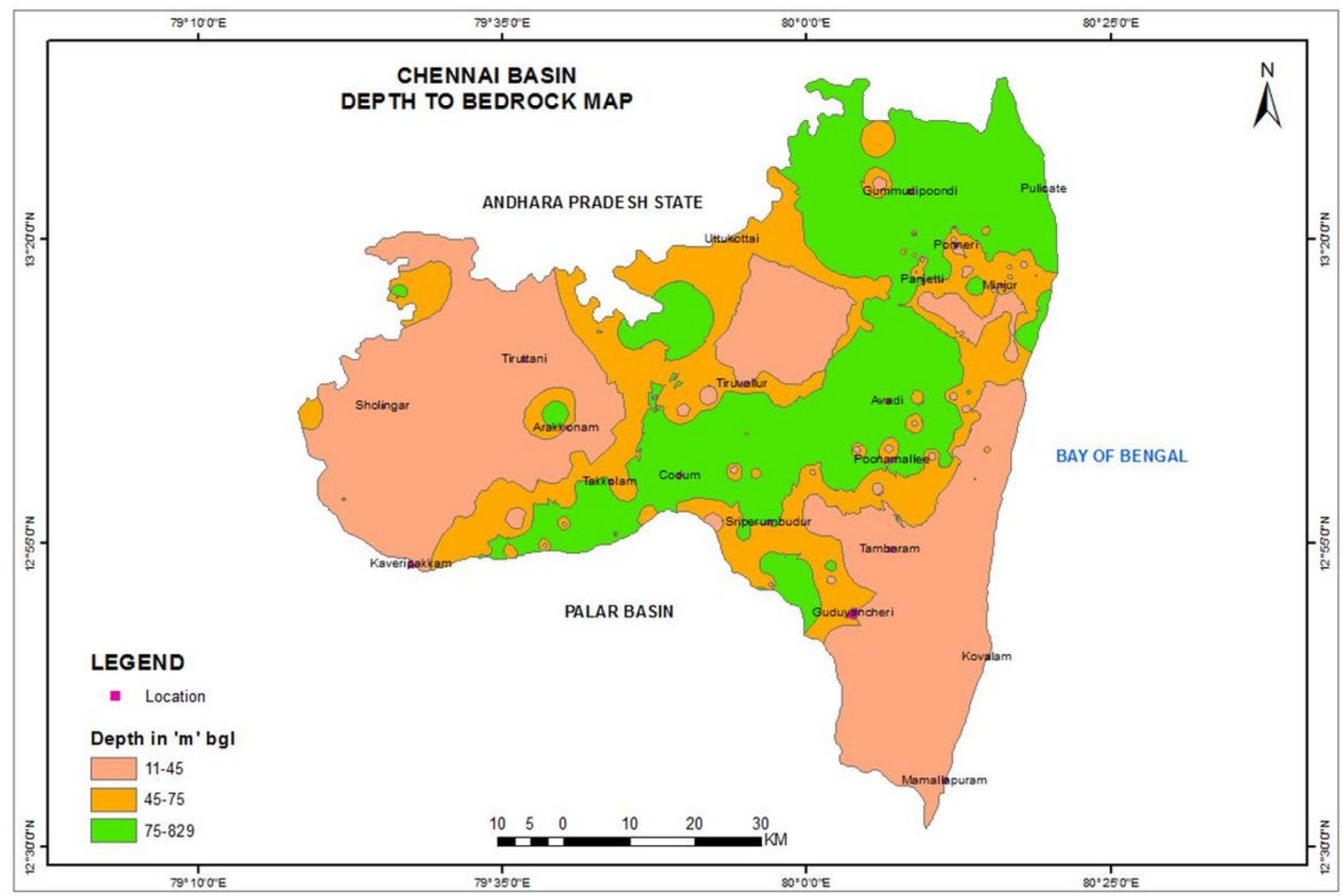

Figure 13

depth to bed rock 


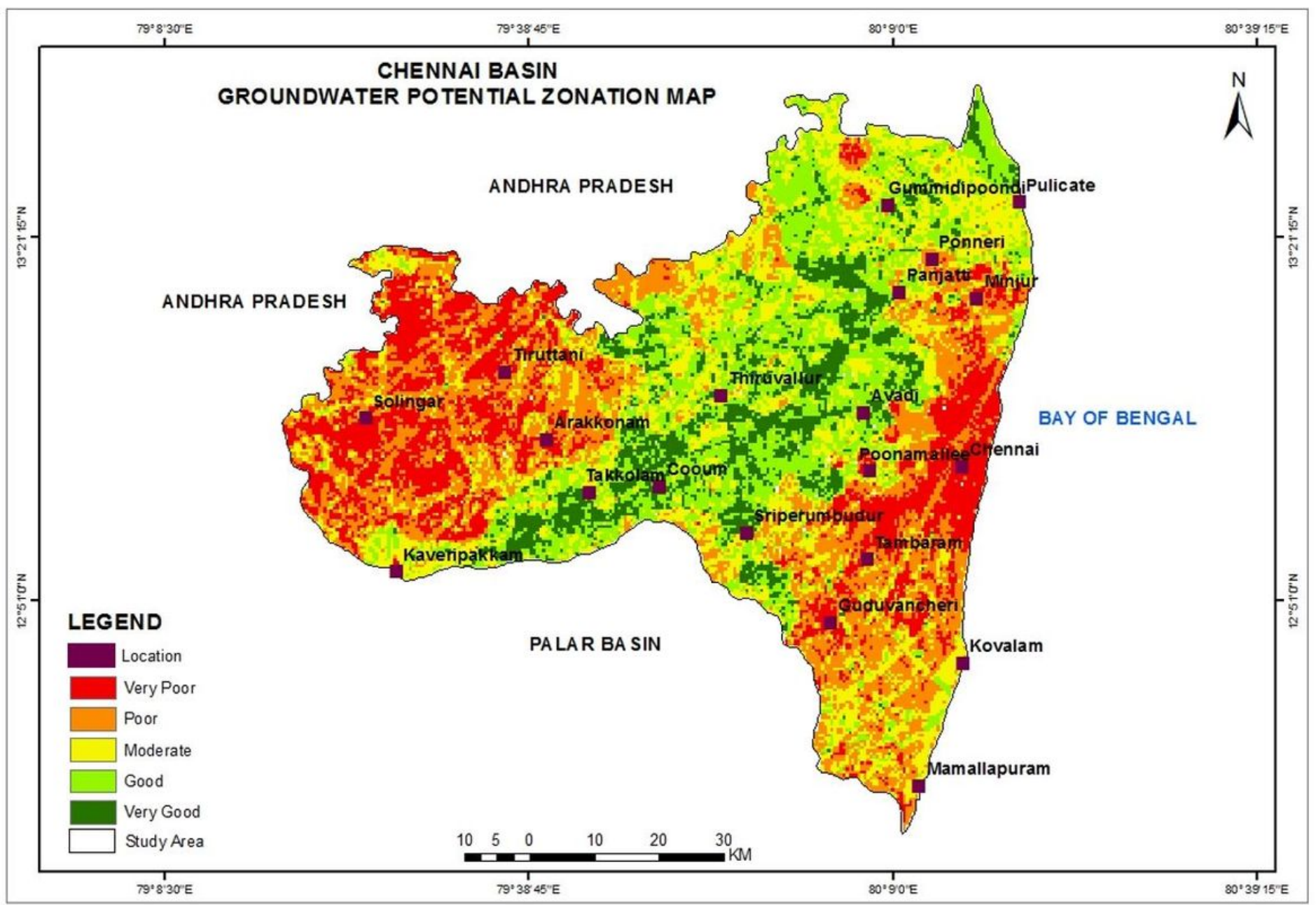

Figure 14

Spatial variation map of Groundwater potential in CRB 